\title{
Benthic-pelagic trophic coupling in an Arctic marine food web along vertical water mass and organic matter gradients
}

\author{
Ashley D. Stasko ${ }^{1,2, *}$, Bodil A. Bluhm ${ }^{3}$, Christine Michel ${ }^{2}$, Philippe Archambault ${ }^{4}$, \\ Andrew Majewski ${ }^{2}$, James D. Reist ${ }^{2}$, Heidi Swanson ${ }^{1}$, Michael Power ${ }^{1}$ \\ ${ }^{1}$ University of Waterloo, Waterloo, Ontario N2L 3G1, Canada \\ ${ }^{2}$ Freshwater Institute, Fisheries and Oceans Canada, Winnipeg, Manitoba R3T 2N6, Canada \\ ${ }^{3}$ UiT - the Arctic University of Norway, Tromsø, Troms 9019, Norway \\ ${ }^{4}$ Université Laval, Québec-Océan, Takuvik, Québec G1V 0A6, Canada
}

\begin{abstract}
Understanding drivers of benthic-pelagic coupling in Arctic marine ecosystems is key to identifying benthic areas that may be sensitive to climatedriven changes in hydrography and surface production. We coupled algal biomass and sedimentary characteristics with stable isotope data for 113 fishes and invertebrates in the Canadian Beaufort Sea and Amundsen Gulf to examine how trophic structure was influenced by the vertical water mass structure and by organic matter input regimes, from 20 to $1000 \mathrm{~m}$ depths. Indices of community-level trophic diversity (isotopic niche size, ${ }^{13} \mathrm{C}$ enrichment relative to a pelagic baseline, and $\delta^{13} \mathrm{C}$ isotopic range) increased from west to east, coincident with the use of more diverse dietary carbon sources among benthic functional groups. Data suggested benthic-pelagic trophic coupling was strongest in the western study region where pelagic sinking flux is relatively high, intermediate in the central region dominated by riverine inputs of terrestrial organic matter, and weakest in the east where strong pelagic grazing is known to limit sinking flux. Differences in $\delta^{13} \mathrm{C}$ between pelagic and benthic functional groups (up to $5.7 \%$ ) increased from west to east, and from the nearshore shelf to the upper slope. On the upper slope, much of the sinking organic matter may be intercepted in the water column, and dynamic hydrography likely diversifies available food sources. In waters $>750 \mathrm{~m}$ there were no clear trends in benthic-pelagic coupling or community-level trophic diversity. This study represents the first description of fish and invertebrate food web structure $>200 \mathrm{~m}$ in the Canadian Beaufort Sea.
\end{abstract}

KEY WORDS: Water column - Benthic food supply · Beaufort Sea $\cdot$ Niche dimensions

*Corresponding author: ashley.stasko@dfo-mpo.gc.ca

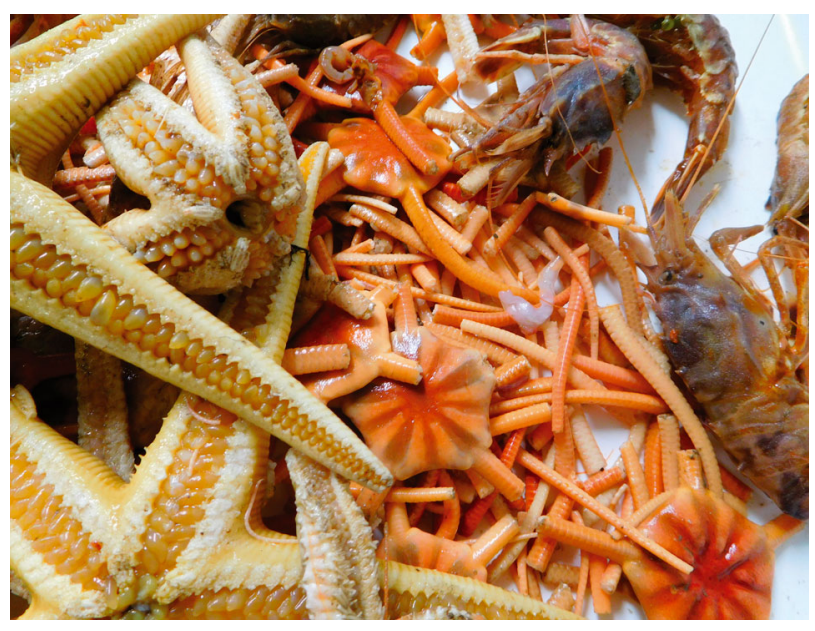

Mobile benthic predators and scavengers collected in the Canadian Beaufort Sea.

Photo: Rachel Hussherr / CBS-MEA, Fisheries and Oceans Canada

\section{INTRODUCTION}

Benthic communities in Arctic seas are primarily fuelled by vertical and/or lateral flux of particulate organic carbon (POC) produced at the surface by pelagic algae, or in nearshore areas by benthic algae and macrophytes (e.g. Grebmeier et al. 2015, Renaud et al. 2015). Some Arctic shelves, such as in the Chukchi Sea, are characterized by high primary production and high sinking POC flux (e.g. Grebmeier et al. 2015). The resulting productive benthic food webs are tightly linked with surface production (i.e.

() The authors 2018. Open Access under Creative Commons by Attribution Licence. Use, distribution and reproduction are unrestricted. Authors and original publication must be credited. 
strong trophic coupling between benthic and pelagic food webs). Other areas experience limited sinking flux either from low surface production or high biological interception in the upper water column (Forest et al. 2010, Iken et al. 2010). Where downward flux is low, substantial benthic secondary production may still be supported by the advection or entrainment of marine POC from nearby regions (Feder et al. 2011), or by the active biological transport of food via vertically migrating biota (e.g. Connelly et al. 2014, Stasko et al. 2016). In addition, terrestrial carbon from river discharge and shoreline erosion is increasingly recognized as an important energy source for some Arctic benthic communities (Dunton et al. 2006, 2012, Feder et al. 2011). Understanding how spatial patterns of water movement and organic matter input influence benthic-pelagic trophic coupling is key to identifying Arctic marine ecosystems that are sensitive to climate-driven changes in surface production (Wassmann \& Reigstad 2011).

Oceanographic conditions that regulate organic matter production and flux undergo relatively abrupt transitions where water masses meet (Belkin et al. 2009). Water mass boundaries influence faunal distributions and trophic properties at all levels of the consumer food web, from zooplankton to marine birds and marine mammals (Bost et al. 2009, Smoot \& Hopcroft 2017). Most studies in high latitude seas have compared food web structure relative to oceanic fronts between adjacent water masses that meet at the surface (Carroll et al. 2008, Brandt et al. 2014). For example, benthic food web structure in the Chukchi Sea varies with the longitudinal distribution of nutrient-rich and nutrient-poor water masses (Iken et al. 2010). In contrast, water masses in the neighbouring Canadian Beaufort Sea (CBS) and Amundsen Gulf (AG) have a vertical structure that can be simplified into 4 distinct and relatively stable layers (see Fig. 1; McLaughlin et al. 1996, 2005). Little is known of how vertical water mass structure affects Arctic benthic food webs. However, significant spatial differences in benthic fish and zooplankton community composition align with major depth-stratified water mass boundaries along the CBS continental slope (Majewski et al. 2017, Smoot \& Hopcroft 2017). Water mass alignment may therefore be important in structuring benthic communities at high latitudes, regardless of whether alignment is primarily vertical or horizontal.

In addition to water mass structure, large to mesoscale alongshore and depth-mediated patterns in organic matter inputs, near-surface pelagic algal production, and POC sinking flux affect linkages between benthic and pelagic communities, and there- fore affect benthic food web structure (Renaud et al. 2007a, Darnis et al. 2012, Kopp et al. 2015, Roy et al. 2015). In areas where the water mass abutting the seafloor depends on water column depth, the hydrographic conditions experienced by the benthos can differ substantially from those that govern surface production or vertical POC flux. Under such conditions, it remains unclear whether Arctic fish and invertebrate food web structure is more strongly influenced by hydrographic conditions at the seafloor (e.g. Feder et al. 2011), or by the gradient in overlying organic matter inputs (e.g. Iken et al. 2010).

We examined linkages between trophic structure and water mass distributions in the southern CBS and AG. The study area is characterized by known alongshore patterns of organic matter inputs, and includes habitats from 20 to $1000 \mathrm{~m}$ deep (see 'Study area and hydrography' below). Trophic niche metrics calculated from stable isotope ratios of nitrogen $\left(\delta^{15} \mathrm{~N}\right.$; indicator of trophic position) and carbon $\left(\delta^{13} C_{i}\right.$ indicator of dietary carbon source, e.g. Peterson \& Fry 1987) measured in marine consumers were paired with pelagic algal biomass measurements and sedimentary analyses to assess if benthic trophic structure and trophic coupling with pelagic food webs varied with spatial patterns of (1) vertical water mass structure inferred from temperature and salinity profiles, (2) by overlying regimes of organic matter inputs along a longitudinal west-to-east gradient, or (3) both. We expected that stronger benthic-pelagic trophic coupling would occur in nearshore habitats and in habitats directly under nutrient-rich water masses, where fresh, marine-derived POC is expected to be more accessible at the seafloor (Tamelander et al. 2006, Iken et al. 2010, Kopp et al. 2015). Alongshore patterns in organic matter inputs are also expected to be linked to benthic-pelagic trophic coupling in shallow nearshore habitats (Juul-Pedersen et al. 2008, Bell et al. 2016), with strong benthic-pelagic coupling in regions with relatively high local primary production (Renaud et al. 2007a, Iken et al. 2010, Sallon et al. 2011).

\section{MATERIALS AND METHODS}

\section{Study area and hydrography}

Published productivity and hydrographic regimes in the study area were used to delineate regional groupings for analyses, and are therefore described here. The southern CBS region is defined by the relatively narrow Mackenzie continental shelf, which extends approximately $120 \mathrm{~km}$ offshore (Fig. 1a). 

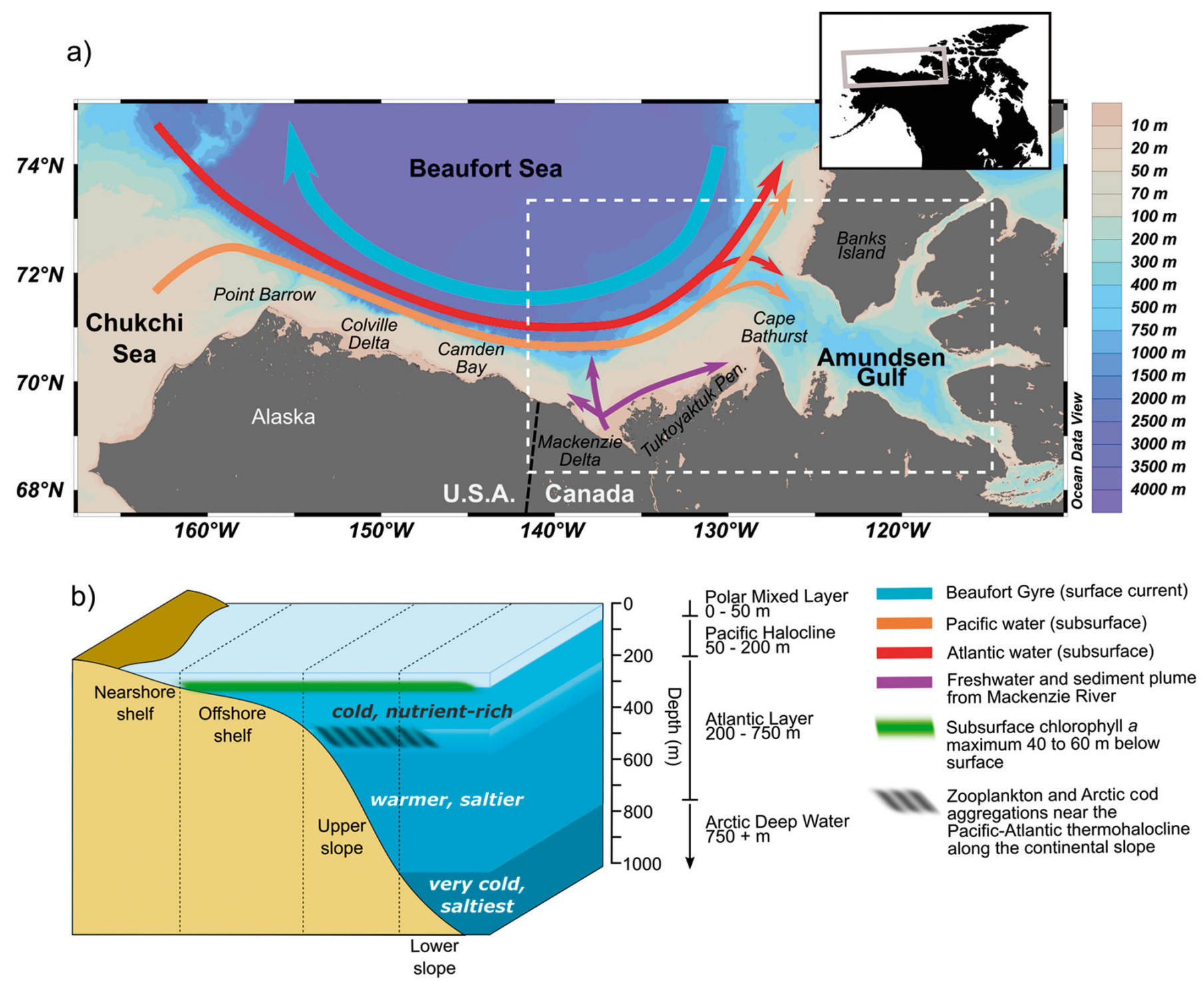

\section{c) Inset from (a)}

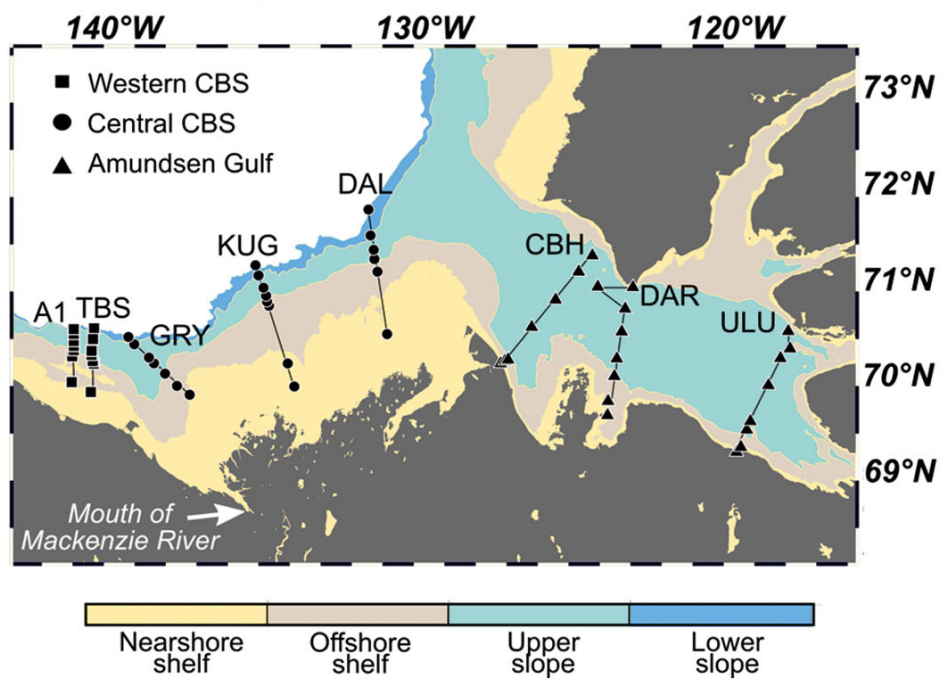

Fig. 1. Map and oceanographic setting for the study region. (a) Surface and subsurface circulation in the Beaufort Sea and Amundsen Gulf. White dashed box: area from which samples were collected. (b) Simplified 4-layer water mass structure in the Canadian Beaufort Sea (CBS) and Amundsen Gulf. Water mass assemblages are separated by vertical dotted lines (McLaughlin et al. 1996, 2005, Lansard et al. 2012). (c) Positions of sampling transects and stations; colours correspond to the spatial extent of each water mass assemblage delineated in (b) 
Past the shelf-break, the seafloor slopes steeply to several thousand meters. The shelf is much narrower in the semi-enclosed AG where maximum depths are approximately $600 \mathrm{~m}$. Open-water surface circulation in the CBS is typically dominated by easterly winds that push surface waters seaward in the anticyclonic Beaufort Gyre (Fig. 1a; Carmack \& Macdonald 2002). Below the surface, circulation is topographically steered eastwards, bringing waters of Pacific and Atlantic origin along the slope and into the CBS (Fig. 1a; Carmack \& Macdonald 2002). The Mackenzie Shelf in the central CBS is strongly influenced by the Mackenzie River, which discharges $>330 \mathrm{~km}^{3}$ of fresh water and up to $130 \times 10^{6} \mathrm{t}$ of sediment annually, exceeding the sediment input of any other Arctic river (Macdonald et al. 1998). The Mackenzie River sediment and freshwater plume typically flows eastward along the Tuktoyaktuk Peninsula, but can be forced offshore and westward under the influence of easterly winds (Fig. 1a; Carmack \& Macdonald 2002). Circulation in the AG is more variable than in the CBS and is poorly understood, but Atlantic and Pacific waters primarily enter from the Beaufort Sea (Barber et al. 2010).

Water mass structure in the Beaufort Sea region can be simplified into 4 vertically stacked layers established by differences in water origin, salinity, temperature, and chemical composition (Fig. 1b; described by McLaughlin et al. 1996, 2005, Lansard et al. 2012). A low-salinity surface layer up to $\sim 50 \mathrm{~m}$ thick, known as the Polar Mixed Layer, is formed by wind mixing of seasonal freshwater inputs with marine waters. Underneath, the Pacific Halocline extends from 50 to $200 \mathrm{~m}$ depths, forming a cold, complex layer of Pacific-origin water with variable salinity. A strong thermohalocline around $200 \mathrm{~m}$ marks the relatively narrow transition between the Pacific Halocline and the warmer, saltier Atlantic Layer below. An important distinction between the Pacific Halocline and Atlantic Layer is that Pacific-origin waters have higher nutrient concentrations $\left(\sim 1 \mu \mathrm{mol} \mathrm{kg}{ }^{-1}\right.$ more phosphate for any given nitrate concentration; Jones et al. 1998). Finally, the Atlantic Layer transitions into the very cold and saline Arctic Deep Water, also of Atlantic origin, at $\sim 750$ to $800 \mathrm{~m}$ depths across a relatively diffuse pycnocline. Simplified vertical water mass structure in the AG is generally similar to that in the CBS, except for the absence of Arctic Deep Water because the AG is not deep enough to receive it.

Longitudinal patterns of primary production in the Beaufort Sea region vary both within and among years (Carmack et al. 2004, Morata et al. 2008, Ardyna et al. 2013), but recent estimates from a large database of historical chlorophyll a (chl a) profiles indicate that annual primary production is relatively high in the Chukchi Sea to the west $\left(\sim 100 \mathrm{~g} \mathrm{C} \mathrm{m}^{-2}\right.$ $\mathrm{yr}^{-1}$ ) and the Canadian Archipelago to the east $\left(\sim 140 \mathrm{~g} \mathrm{C} \mathrm{m}^{-2} \mathrm{yr}^{-1}\right)$, and considerably lower in the Beaufort Sea ( 62 $\mathrm{g} \mathrm{C} \mathrm{m}^{-2} \mathrm{yr}^{-1}$; Ardyna et al. 2013). In the AG, frequent upwelling of nutrient-laden Pacific water and a polynya near Cape Bathurst cause local productivity hotspots, which influence inter-annual variability in primary production and downward particle flux (Sallon et al. 2011).

\section{Sample collection and processing}

Sampling was conducted by the Beaufort Regional Environmental Assessment Marine Fishes Project (Fisheries and Oceans Canada) aboard the stern trawler FV 'Frosti' during the ice-free season from early August to early September of 2012 and 2013. Samples were collected along 8 transects that spanned the continental shelves and slopes of the CBS and AG, each with 5 to 8 pre-defined sampling stations at depths of 20,40, 75, 200, 275, 300, 350, 450, 500, 750, or $1000 \mathrm{~m}$ (Fig. 1c). Fish and benthic macroinvertebrates were collected with a combination of 2 demersal trawl nets: a modified Atlantic Western IIA benthic otter trawl (13 mm cod end liner) and a $3 \mathrm{~m}$ high-rise benthic beam trawl (6.3 mm mesh cod end liner). Macrozooplankton were collected using a Bongo net (500 $\mu \mathrm{m}$ mesh) towed obliquely from $200 \mathrm{~m}$ to surface (or from near bottom where sampling depths were shallower).

Marine sediments were collected with a $0.25 \mathrm{~m}^{2}$ USNEL box core. The upper $1 \mathrm{~cm}$ of sediment was sampled for stable isotope analysis, organic matter (OM) content, and $\mathrm{chl}$ a. The upper $5 \mathrm{~cm}$ were sampled with a $60 \mathrm{cc}$ truncated syringe for granulometry. Remaining sediments ( $25 \mathrm{~cm}$ core) were sieved through a $1 \mathrm{~mm}$ stainless steel mesh to collect macroinfauna for stable isotope analysis. Sediment samples were frozen immediately at $-50^{\circ} \mathrm{C}$. Sediment chl $a$ and phaeopigment concentrations were analysed fluorometrically following a modified protocol by Riaux-Gobin \& Klein (1993) in a Turner Design 20 fluorometer after a $24 \mathrm{~h}$ extraction in $90 \%$ acetone at $4^{\circ} \mathrm{C}$ in the dark. Sediment OM content ( $\%$ of total dry weight) was determined as loss-after-ignition following combustion for $6 \mathrm{~h}$ at $550^{\circ} \mathrm{C}$. Sediment grain size analysis was performed on a minimum of 9 replicates of wet sediment using a LS13 320 laser diffraction type granulometer (Beckman Coulter) with polarization intensity differential scattering. Prior to analysis, sediments were mixed with a 20 
$\mathrm{gl}^{-1}$ solution of $\left(\mathrm{NaPO}_{3}\right)_{6}$ as a dispersant and shaken for $24 \mathrm{~h}$ to break aggregates.

Data of oceanographic temperature and salinity profiles, taken at each station with a Seabird SBE-25 conductivity, temperature, and depth probe, were provided by collaborators in the sampling program and are published in Niemi et al. (2015) and Eert et al. (2015). Duplicate seawater sub-samples from the chlorophyll maximum depth, which can occur as deep as $50 \mathrm{~m}$ below the surface in the region (Carmack et al. 2004), were collected with a rosette equipped with 12 Niskin bottles. Water samples were filtered onboard onto Whatman $25 \mathrm{~mm}$ GF/F filters and extracted in $90 \%$ acetone for 18 to $24 \mathrm{~h}$ at $4^{\circ} \mathrm{C}$ in the dark. Chl a biomass was then determined using a Turner Designs 10AU fluorometer calibrated using pure chl a from Anacystis nidulans (Sigma Chemicals), according to Parsons et al. (1984).

Biota collected for stable isotope analyses were sorted to the lowest possible taxonomic resolution, rinsed with seawater and frozen immediately at $-50^{\circ} \mathrm{C}$. Where taxonomic doubt existed, voucher specimens were preserved in a formaldehyde seawater solution for later verification by taxonomists (see 'Acknowledgements'). Taxonomy was standardized to the currently accepted names in the World Register of Marine Species (WoRMS Editorial Board 2016). A representative subset of taxa was selected for stable isotope analysis on the basis of ubiquity, relative abundance, and taxonomic diversity as assessed during field collection; we aimed to collect and analyze a minimum of 3 samples taxon ${ }^{-1}$ in each water mass assemblage (see Supplement 1 at www.int-res.com/ articles/suppl/m594p001_supp1.xls). Where necessary due to small body size (e.g. zooplankton), multiple individuals of the same taxon from the same station were pooled for analysis. Fish and macroinvertebrates were sampled across the observed range of body sizes to account for potential covariation between $\delta^{15} \mathrm{~N}$ and size (e.g. Romanuk et al. 2011). The index of taxonomic distinctness based on presence/ absence data $\left(\Delta^{+} ;\right.$Clarke \& Warwick 1998$)$ was used to determine that the species subset selected for stable isotope analysis did not deviate significantly from expectation based on the full list of observed species (observed values did not fall outside of the $90 \%$ confidence limits of expected values).

\section{Classification of trophic functional groups}

Taxa were divided into 9 functional groups using information derived from published trophic marker analyses, feeding observations, and previous classifications (see Supplement 1). Classification was based on systems proposed by Macdonald et al. (2010) and Jumars et al. (2015) using trophic traits relevant to our study: primary feeding habitat (benthic, pelagic, benthopelagic, sediment surface, sediment subsurface), trophic type (carnivore, herbivore), and further subdivided into major feeding modes for the benthic omnivorous taxa (suspension feeder, deposit feeder, and facultative suspension feeders/surface deposit feeders; Table 1). See Supplement 1 for a full list of taxa, their classifications, and supporting information from the literature.

Fish commonly undergo ontogenetic shifts in habitat or resource use (Garrison \& Link 2000 and references therein). We conducted a literature review of available stomach contents, size distribution, and length-at-age data for each fish species to identify potential ontogenetic diet shifts between benthic and pelagic prey that would affect their functional group membership (see references in Supplement 1). Diet data were scarce for many species, but where available indicated no switch between pelagic and benthic feeding, except for Arctic cod Boreogadus saida (e.g. Matley et al. 2013) and Atlantic poacher Leptagonus decagonus (Källgren et al. 2015). Consequently, we used standard body length to divide Arctic cod into pelagic $(<80 \mathrm{~mm})$ and benthopelagic $(>80 \mathrm{~mm}$ ) functional groups, and Atlantic poacher into benthopelagic $(<85 \mathrm{~mm})$ and benthic $(>85 \mathrm{~mm})$ groups.

\section{Delineation of vertical water mass structure and longitudinal regions}

To assess food web structure along a longitudinal gradient of OM input regimes, sampling sites were divided into 3 regions that differed in the magnitude of published annual primary production estimates (see 'Study area and hydrography' above; Carmack et al. 2004, Morata et al. 2008, Ardyna et al. 2013). The 'western CBS' region included transects immediately west of the Mackenzie River delta on the American Beaufort Shelf (A1 and TBS), the 'central CBS' region included transects on the Mackenzie Shelf that are regularly influenced by the Mackenzie River plume (GRY, DAL, and KUG; Magen et al. 2010), and the ' $A G$ ' region included transects to the east of the CBS $(\mathrm{CBH}, \mathrm{DAR}$ and ULU; Fig. 1c).

Sites within each longitudinal region were further divided to assess the influence of vertical water 
Table 1. Functional trophic groups used in this study. See Supplement 1 at www.int-res.com/articles/suppl/m594p001_supp1.xls for further details and references

\begin{tabular}{|lc|}
\hline Functional group & Description \\
\hline Pelagic herbivore & Zooplankton in the pelagic realm that feed primarily on photosynthetic, and occa- \\
& sionally heterotrophic, organisms \\
Pelagic carnivore & Animals restricted to feeding in the upper pelagic realm on other animals. Includes \\
& predatory amphipods, molluscs, cnidarians, chaetognaths, ctenophores, and some \\
& fishes \\
Benthopelagic carnivore & Highly mobile fishes and invertebrates known to feed carnivorously at and above \\
& the seafloor as predators, scavengers, or both. May consume a mix of benthic and \\
& pelagic prey. Some taxa may make substantial vertical migrations into the upper \\
& water column \\
Benthic suspension feeder & Omnivorous animals known to live on the seafloor and feed on fresh or re-suspended \\
(SF) & particulate organic matter (no restriction is made on particle size) \\
Benthic suspension and surface & Omnivorous animals known to live on the seafloor that can switch between the \\
deposit feeder (SDF/SF) & 2 feeding strategies depending on food availability \\
Benthic surface deposit feeder & Omnivorous animals known to live on the seafloor and feed on deposited material \\
(SDF) & on the sediment surface including, but not limited to, food falls, detritus, bacteria, \\
Benthic subsurface deposit & and bacterial products \\
feeder (SSDF) & Omnivorous animals known to feed below the surface of the sediment on \\
Benthic subsurface (SS) carnivore & detritus and/or bacterial products \\
Benthic carnivore & Mostly predatory marine worms that feed carnivorously on animals below the \\
& surface of the sediment \\
& Animals that live on the seafloor and feed carnivorously as predators, scavengers or \\
& both. May consume some portion of pelagic resources in the form of food falls or \\
& vertically migrating prey \\
&
\end{tabular}

column properties on food web structure. Boundary depths between water masses were delineated using temperature, salinity, and nutrient profiles taken at each sampling station by collaborators, following the water mass characteristics described by McLaughlin et al. (1996, 2005) and Lansard et al. (2012). Water mass boundaries were stable between sampling years (see data in Eert et al. 2015, Niemi et al. 2015). Following McLaughlin et al. (1996), we use the term 'water mass assemblage' to refer to the unique set of vertically stratified water masses that occupy the water column in a given area. We defined 4 primary water mass assemblages, named for their position along the slope: (1) the 'nearshore shelf', which contained stations with bottom sampling depths from 20 to $40 \mathrm{~m}$ within the Polar Mixed Layer; (2) the 'offshore shelf', with sampling station depths from 75 to $200 \mathrm{~m}$ within the Pacific Halocline; (3) the 'upper slope', with sampling station depths from 275 to $500 \mathrm{~m}$ within the Atlantic Layer; and (4) the 'lower slope', with sampling station depths from 750 to 1000 m within Arctic Deep Water (Fig. 1b). A total of 11 regional communities were therefore analysed for isotopic trophic structure: 3 regions, each of which contained 4 water mass assemblages, except in the AG where the lower slope assemblage is absent.

\section{Stable isotope analysis and isotopic niche metrics}

Tissues dissected for stable isotope analysis included dorsal muscle for fish, whole body for zooplankton and small infauna, and various slow turnover tissues consistent with literature practices for large invertebrates (muscle tissues, internal viscera, or whole body where exoskeleton could not be easily removed from soft tissues; e.g. Dunton et al. 2006, Stasko et al. 2017). Samples were dehydrated in a standard laboratory convection oven at $50^{\circ} \mathrm{C}$ for a minimum of $48 \mathrm{~h}$ until dry (fish and sediments) or a FreeZone 18 freeze-drier (Labconco; benthic invertebrates and zooplankton). Dried samples were ground to a homogenous powder and analysed for $\mathrm{N}$ and $\mathrm{C}$ isotopic composition using a Delta Plus continuous flow isotope spectrometer (Thermo-Finnigan) coupled to a 4010 elemental analyzer (Costech Instruments) at the University of Waterloo Environmental Isotopes Laboratory. Prior to the determination of $\delta^{13} \mathrm{C}$, subsamples of sediment and invertebrates that contained carbonate were acidified with $1 \mathrm{~N} \mathrm{HCl}$ to remove inorganic carbon following Jacob et al. (2005). Elemental isotope ratios $\left({ }^{15} \mathrm{~N}:{ }^{14} \mathrm{~N},{ }^{13} \mathrm{C}:{ }^{12} \mathrm{C}\right)$ were expressed in standard $\delta$ notation as parts per thousand (\%) relative to the international standards Vienna Pee Dee Belemnite for car- 
Table 2. Unadjusted $\delta^{15} \mathrm{~N}$ and $\delta^{13} \mathrm{C}$ values for the baseline pelagic primary consumer Calanus hyperboreus and for sediment, by water mass assemblage and longitudinal region (CBS: Canadian Beaufort Sea). Number (n) of samples analysed refers to bulk samples. Values are mean \pm SD (if $n>2$ ), or mean \pm range (if $n=2$ ). Stable isotope values for individual taxa can be found in Stasko et al. (2017)

\begin{tabular}{|c|c|c|c|c|c|c|c|}
\hline \multirow{2}{*}{$\begin{array}{l}\text { Water mass } \\
\text { assemblage }\end{array}$} & \multirow{2}{*}{ Region } & \multicolumn{3}{|c|}{ C. hyperboreus } & \multirow[b]{2}{*}{$\mathrm{n}$} & Sedimen & \multirow{2}{*}{$\delta^{13} \mathrm{C}(\%)$} \\
\hline & & $\mathrm{n}$ & $\delta^{15} \mathrm{~N}(\%)$ & $\delta^{13} \mathrm{C}(\%)$ & & $\delta^{15} \mathrm{~N}(\%)$ & \\
\hline \multirow[t]{3}{*}{ Nearshore shelf } & Western CBS & 1 & 9.2 & -26.2 & 1 & 3.8 & -24.8 \\
\hline & Central CBS & 3 & $8.7 \pm 0.2$ & $-26.8 \pm 0.6$ & 3 & $3.3 \pm 0.9$ & $-25.9 \pm 0.3$ \\
\hline & Amundsen Gulf & 3 & $10.2 \pm 0.7$ & $-27.4 \pm 0.3$ & 3 & $4.7 \pm 2.0$ & $-17.1 \pm 11.9$ \\
\hline \multirow[t]{3}{*}{ Offshore shelf } & Western CBS & 2 & $10.4 \pm 0.7$ & $-25.8 \pm<0.1$ & 3 & $4.7 \pm 0.3$ & $-24.8 \pm 0.1$ \\
\hline & Central CBS & 6 & $8.8 \pm 0.3$ & $-26.8 \pm 0.4$ & 7 & $4.0 \pm 0.8$ & $-25.5 \pm 0.3$ \\
\hline & Amundsen Gulf & 11 & $10.3 \pm 0.5$ & $-27.3 \pm 0.3$ & 11 & $4.2 \pm 2.5$ & $-14.7 \pm 9.1$ \\
\hline \multirow[t]{3}{*}{ Upper slope } & Western CBS & 2 & $8.7 \pm 0.1$ & $-27.1 \pm<0.1$ & 3 & $5.3 \pm 0.1$ & $-24.5 \pm 0.2$ \\
\hline & Central CBS & 6 & $9.0 \pm 0.7$ & $-27.1 \pm 0.6$ & 7 & $4.2 \pm 0.3$ & $-25.0 \pm 0.2$ \\
\hline & Amundsen Gulf & 9 & $10.4 \pm 0.4$ & $-27.4 \pm 0.3$ & 9 & $6.7 \pm 0.9$ & $-20.7 \pm 5.5$ \\
\hline \multirow[t]{2}{*}{ Lower slope } & Western CBS & 2 & $9.5 \pm 0.2$ & $-26.5 \pm 0.1$ & 3 & $5.1 \pm 0.3$ & $-24.3 \pm 0.1$ \\
\hline & Central CBS & 6 & $9.2 \pm 0.7$ & $-27.0 \pm 0.4$ & 6 & $4.9 \pm 0.5$ & $-24.2 \pm 0.4$ \\
\hline
\end{tabular}

bon and atmospheric $\mathrm{N}_{2}$ for nitrogen (Craig 1957, Mariotti 1983). Analytical error for $\delta^{15} \mathrm{~N}$ and $\delta^{13} \mathrm{C}$ during any given sample run did not exceed 0.3 and $0.2 \%$, respectively, based on repeated measurements of working laboratory standard material crosscalibrated to the international standards mentioned above (no less than $20 \%$ of each run). Repeatability of duplicate measurements of sample material was $0.3 \%$ for both $\delta^{15} \mathrm{~N}$ and $\delta^{13} \mathrm{C}$.

Lipids were not extracted from tissues prior to analysis. Lipid extraction can cause significant change in analysed isotope ratios and is often suggested as a solution to avoid confusion between isotopic variability caused by lipids and variability caused by dietary shifts (e.g. Logan et al. 2008). However, it was not feasible to extract lipids from $>4000$ individual samples, or to develop species-specific mathematical correction models for 113 taxa given the noted inappropriateness of multi-taxa models (e.g. Fagan et al. 2011, Mohan et al. 2016). Variation in lipid content, and in the tissue types analysed among taxa, could bias interpretations if patterns in $\delta^{13} \mathrm{C}$ data observed across the regions and water mass assemblages were also linked to lipid content or tissue type. Implications of lipid treatment decisions and other possible methodological bias effects were addressed in a sensitivity analysis detailed in Supplement 2 at www.int-res.com/articles/suppl/ m594p001_supp2.pdf.

A representative primary consumer was used to normalize consumer stable isotope values to account for spatial heterogeneity. Consumer $\delta^{13} \mathrm{C}$ values were converted to a measurement of isotopic enrichment (Clark \& Fritz 1997) relative to a pelagic baseline $\left(\Delta^{13} \mathrm{C}_{\text {pel }}\right)$ as:

$$
\Delta^{13} \mathrm{C}_{\mathrm{pel}_{\mathrm{w}-\mathrm{c}}}=\left(\frac{1000+\delta_{\mathrm{w}}}{1000+\delta_{\mathrm{c}}}-1\right) \times 10^{3}
$$

where $\delta_{\mathrm{c}}$ is the consumer $\delta^{13} \mathrm{C}$ value, and $\delta_{\mathrm{w}}$ is the water mass- or region-specific mean $\delta^{13} \mathrm{C}$ value of the widespread Arctic filter-feeding zooplankter Calanus hyperboreus (Table 2). Consumer $\delta^{15} \mathrm{~N}$ values were baseline-adjusted by subtracting the water mass- or region-specific mean $\delta^{15} \mathrm{~N}$ value of C. hyperboreus from the consumer $\delta^{15} \mathrm{~N}$. We must emphasize that $C$. hyperboreus is not meant to reflect the base of the demersal food web. Rather, C. hyperboreus is a representative pelagic primary consumer that marks a consistent 'starting point' along the $\delta^{13} \mathrm{C}$ continuum as dietary organic carbon is dynamically transformed during sinking, microbial processing, and integration into the benthic food web (e.g. Dunton et al. 1989).

Five metrics derived from the dispersion of stable isotope values in bivariate $\delta^{15} \mathrm{~N}$ versus $\delta^{13} \mathrm{C}$ space were used as proxies for realized dietary niche dimensions (Fig. 2). Isotopic niche metrics were calculated at the community and functional group level using baseline-adjusted $\delta^{15} \mathrm{~N}$ and $\Delta^{13} \mathrm{C}_{\mathrm{pel}}$. (1) Niche region size was calculated as the smallest region in which baseline-adjusted $\delta^{15} \mathrm{~N}$ and $\Delta^{13} \mathrm{C}_{\text {pel }}$ have a $95 \%$ probability of being found (Swanson et al. 2015). Following Layman et al. (2007), (2) the mean $\Delta \Delta^{13} C_{\text {pel }}$ was interpreted as the average position along the benthic-pelagic continuum, while (3) the carbon isotopic range was measured as the range of $\Delta^{13} \mathrm{C}_{\mathrm{pel}}$ values within the niche region and represents the breadth of carbon resources utilized by the sampled population. (4) Mean $\delta^{15} \mathrm{~N}$ was interpreted as the average baseline-adjusted trophic elevation, while (5) nitrogen isotopic range was measured as the 


\section{Western CBS}

Nearshore shelf

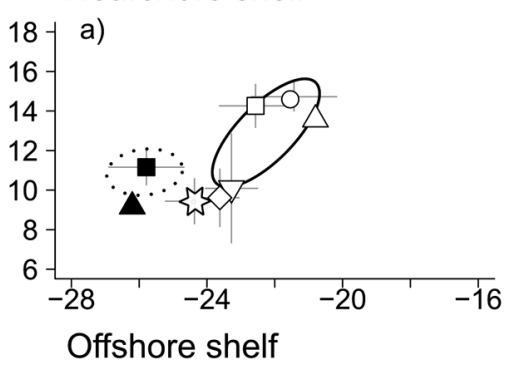

d)

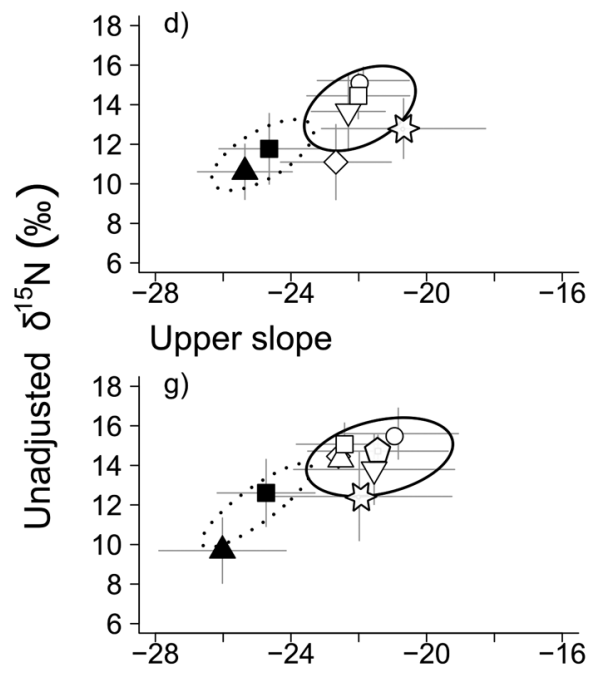

Lower slope

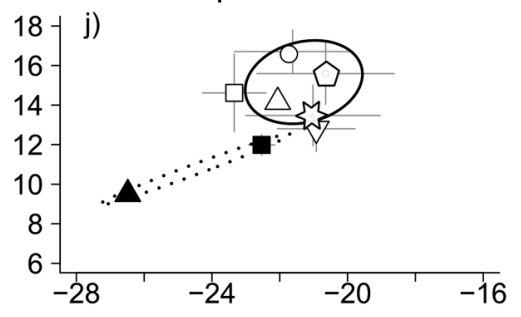

Central CBS
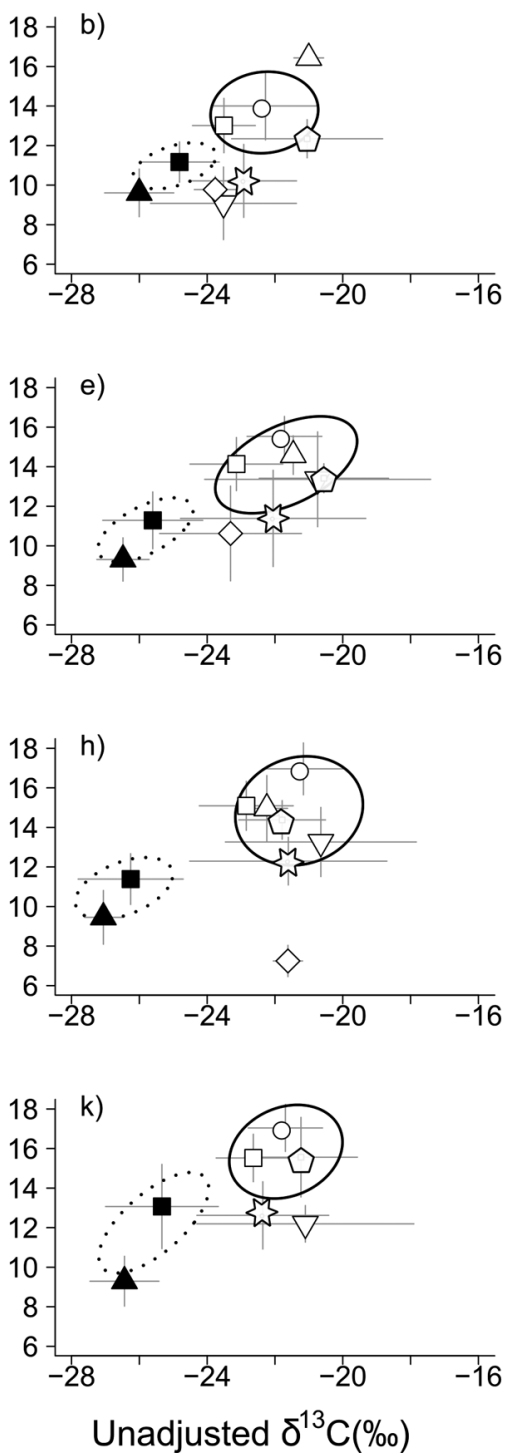

Amundsen Gulf

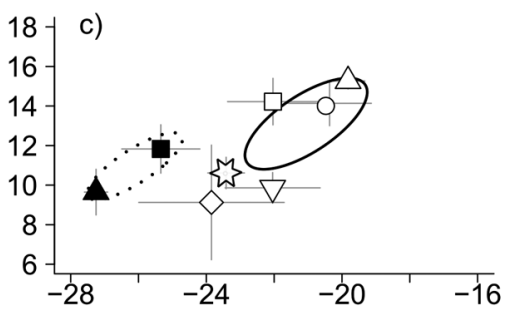

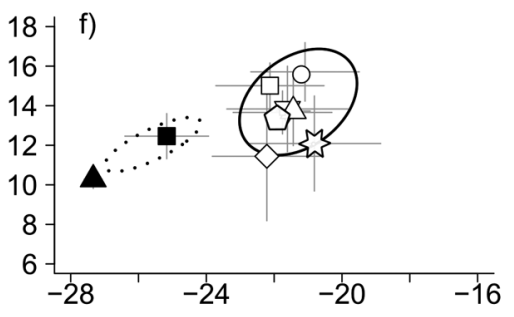

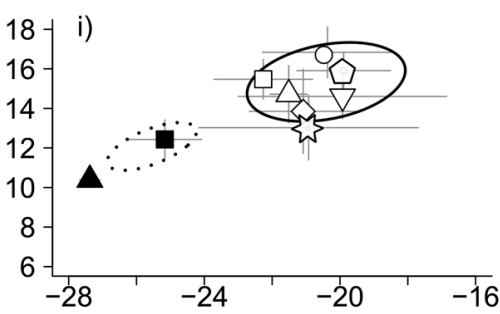

- Pelagic carnivore

$\Delta$ Pelagic herbivore

$\square$ Benthopelagic carnivore

o Benthic carnivore

$\triangle$ Benthic SS carnivore

$\diamond$ Benthic SF

$\nabla$ Benthic SDF/SF

\& Benthic SDF

$\checkmark$ Benthic SSDF

Fig. 2. Mean $\delta^{15} \mathrm{~N}$ versus $\delta^{13} \mathrm{C}$ for 9 functional groups (see Table 1 for abbreviations) within each water mass assemblage, within 3 regions: the western Canadian Beaufort Sea (CBS), the central CBS, and Amundsen Gulf. Benthic functional groups (white) become increasingly separated from pelagic groups (black) along the $\delta^{13} \mathrm{C}$ axis from the western CBS to the Amundsen Gulf in the east (rows), and from the shallow nearshore shelf to the upper slope water mass assemblage (columns). Isotopic niche regions are drawn for benthic (solid ellipse) and pelagic (dotted ellipse) functional groups separately to illustrate isotopic separation

range of baseline-adjusted $\delta^{15} \mathrm{~N}$ values within the niche region and is similar conceptually and computationally to isotopic food web length. All 5 isotopic niche metrics were calculated within a Bayesian framework using the 'nicheROVER' package in $\mathrm{R}$ (Swanson et al. 2015, R Core Team 2016). An uninformative normal-inverse-Wishart prior distribution was used to generate posterior distributions of the niche region centroid and covariance matrix, from which
10000 random permutations were drawn and used to calculate posterior distributions of the niche region size and the 4 other associated niche metrics. The posterior modes and $95 \%$ credible intervals of the niche metrics are reported. At the functional group level, average benthic-pelagic coupling was measured as the mean isotopic separation between benthic and pelagic functional groups along the $\delta^{13} \mathrm{C}$ continuum $(\%)$. 
Table 3. Habitat measurements used as proxies for the availability of pelagic production to the benthos, including total chlorophyll a (chl a) at the subsurface chlorophyll maximum (SCM) depth, sediment chl a (mg $\mathrm{m}^{-2}$ of dry weight), sediment chl a:phaeopigments (Phaeo) ratio, sediment organic matter (OM) content, sediment mean grain size, and sediment C:N ratio. Data for each proxy were averaged within regions and water mass assemblages. No data (nd) were available for sediment organic matter content in the lower slope assemblage of the western Canadian Beaufort Sea (CBS) region

\begin{tabular}{|c|c|c|c|c|c|c|c|}
\hline \multirow{2}{*}{$\begin{array}{l}\text { Water mass } \\
\text { assemblage }\end{array}$} & \multirow[t]{2}{*}{ Region } & \multirow{2}{*}{$\begin{array}{l}\text { Total chl } a \text { at } \\
\text { SCM depth } \\
\left(\mathrm{mg} \mathrm{m}^{-3}\right)\end{array}$} & \multirow[b]{2}{*}{$\begin{array}{c}\mathrm{Chl} \mathrm{a} \\
\left(\mathrm{mg} \mathrm{m}^{-2}\right)\end{array}$} & \multirow{2}{*}{$\begin{array}{l}\text { Sedi } \\
\text { Chl a:Phaeo }\end{array}$} & \multirow{2}{*}{$\begin{array}{l}\text { th characte } \\
\% \text { OM }\end{array}$} & \multirow{2}{*}{$\begin{array}{l}\text { istics } \\
\text { Mean grain } \\
\text { size }(\mu \mathrm{m})\end{array}$} & \multirow[b]{2}{*}{$\mathrm{C}: \mathrm{N}$} \\
\hline & & & & & & & \\
\hline \multirow[t]{3}{*}{ Nearshore shelf } & Western CBS & 0.38 & 21.89 & 0.32 & 7.86 & 32.36 & 9.17 \\
\hline & Central CBS & $0.73 \pm 0.15$ & $11.11 \pm 13.90$ & $0.28 \pm 0.12$ & $8.43 \pm 0.30$ & $10.27 \pm 10.51$ & $9.35 \pm 0.36$ \\
\hline & Amundsen Gulf & $0.56 \pm 0$ & $12.95 \pm 0.77$ & $0.43 \pm 0.09$ & $10.46 \pm 2.66$ & $9.85 \pm 9.43$ & $24.32 \pm 25.27$ \\
\hline \multirow[t]{3}{*}{ Offshore shelf } & Western CBS & $0.35 \pm 0$ & $2.67 \pm 0.11$ & $0.16 \pm 0.07$ & $7.97 \pm 1.08$ & $12.31 \pm 6.86$ & $6.73 \pm 1.37$ \\
\hline & Central CBS & $0.37 \pm 0.05$ & $2.65 \pm 1.60$ & $0.12 \pm 0.04$ & $7.42 \pm 1.86$ & $34.57 \pm 69.89$ & $9.19 \pm 0.60$ \\
\hline & Amundsen Gulf & $0.5 \pm 0.14$ & $5.68 \pm 3.35$ & $0.18 \pm 0.09$ & $10.01 \pm 2.29$ & $12.02 \pm 5.15$ & $20.33 \pm 13.89$ \\
\hline \multirow[t]{3}{*}{ Upper slope } & Western CBS & $0.44 \pm 0.20$ & $2.76 \pm 1.64$ & $0.15 \pm 0.08$ & 9.40 & $5.88 \pm 1.31$ & $7.15 \pm 0.56$ \\
\hline & Central CBS & $0.41 \pm 0.08$ & $1.88 \pm 0.22$ & $0.10 \pm 0.01$ & $8.54 \pm 0.17$ & $5.48 \pm 2.18$ & $8.82 \pm 1.30$ \\
\hline & Amundsen Gulf & $0.55 \pm 0.15$ & $2.13 \pm 0.99$ & $0.14 \pm 0.04$ & $11.57 \pm 1.87$ & $8.82 \pm 2.68$ & $8.92 \pm 5.42$ \\
\hline \multirow[t]{2}{*}{ Lower slope } & Western CBS & $0.39 \pm 0.03$ & $0.69 \pm 0.59$ & $0.06 \pm 0.02$ & nd & $4.89 \pm 1.58$ & $7.81 \pm 0.73$ \\
\hline & Central CBS & $0.34 \pm 0.04$ & $0.24 \pm 0.16$ & $0.05 \pm 0.01$ & $8.79 \pm 0.43$ & $3.86 \pm 0.18$ & $7.65 \pm 0.71$ \\
\hline
\end{tabular}

\section{Association between trophic structure and proxies for OM input}

To relate spatial variation in trophic structure to spatial gradients of marine POC deposition, 6 measurements were chosen as proxies for the availability of pelagic production to the benthos (Morata et al. 2011, Roy et al. 2014, 2015). Average total chl a at the subsurface chlorophyll maximum depth $\left(\mathrm{mg} \mathrm{m}^{-3}\right)$ was used as a proxy for pelagic primary production, assuming a linear relationship between the 2 (Matrai et al. 2013). Chl a concentrations ( $\mathrm{mg} \mathrm{m} \mathrm{m}^{-2}$ of dry weight) and \% OM of surface sediments were used as proxies for marine POC input to the seafloor, where higher values usually indicate greater availability of fresh marine OM (Roy et al. 2014, Cooper et al. 2015). The ratio between sedimentary concentrations of chl $a$ and phaeopigments (a degradation product of chl a) was used as an indicator for the freshness of algal-derived OM, where higher values indicate higher degradation (e.g. Morata et al. 2011). Mean grain size $(\mu \mathrm{m})$ and $C: N$ ratio of surface sediments were used as indicators of OM deposition rates, where finer sediments and lower $\mathrm{C}: \mathrm{N}$ are usually associated with areas of high OM deposition (Cooper et al. 2015). Proxies were averaged across sites within each of the 11 regional communities (Table 3). Regressions were used to assess the significance of linear relationships between isotopic trophic niche metrics and each production/deposition proxy. Pearson correlation analyses between all possible pairs of proxies were used to assess whether indices of high pelagic POC deposition were signifi- cantly related to each other. Linear models met all parametric assumptions. Robust regressions with MM estimation were used to identify outliers (Rousseuw \& Leroy 1987). Linear regressions and correlations were considered significant at $\alpha=0.05$.

All statistical and graphical procedures were performed in R v.3.3.1 (R Core Team 2016) using the packages 'ggplot2', 'gridExtra', 'nicheROVER', 'plyr', 'robustbase', and 'vegan'.

\section{Data reporting}

Full station profiles of water temperature, salinity, and nutrient concentrations are freely available through federal Canadian Data Reports of Hydrography and Ocean Sciences (Eert et al. 2015, Niemi et al. 2015). The $\delta^{15} \mathrm{~N}, \delta^{13} \mathrm{C}$, and $\mathrm{C}: \mathrm{N}$ for all individual taxa, averaged by region and water mass assemblage, are also freely available through a Canadian Data Report of Fisheries and Aquatic Sciences (Stasko et al. 2017). Data reports can be accessed through the Federal Science Library (http://science-libraries.canada.ca/ eng/home/).

\section{RESULTS}

\section{Influence of longitudinal gradient in OM inputs}

When analysed across regions for any given water mass assemblage, community-level niche region size, mean $\Delta{ }^{13} \mathrm{C}_{\text {pel }}$, and carbon isotopic range generally 
- Western CBS O Central CBS $\triangle$ Amundsen Gulf

a)

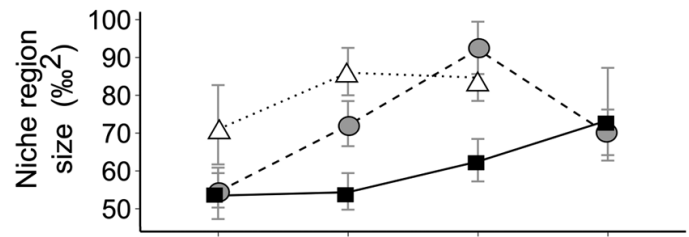

b)

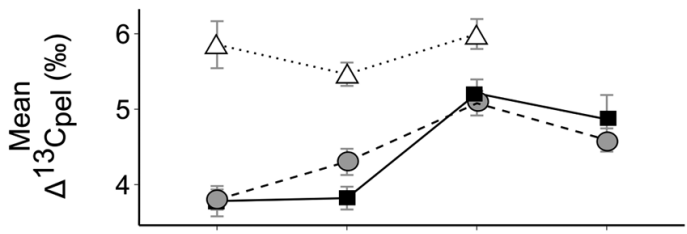

c)

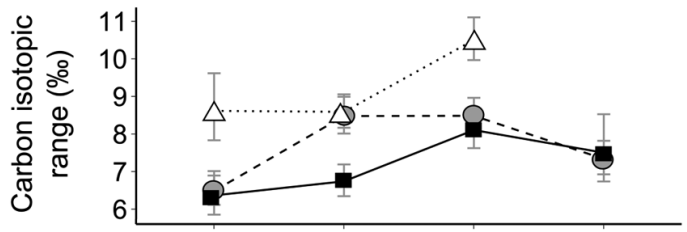

d)

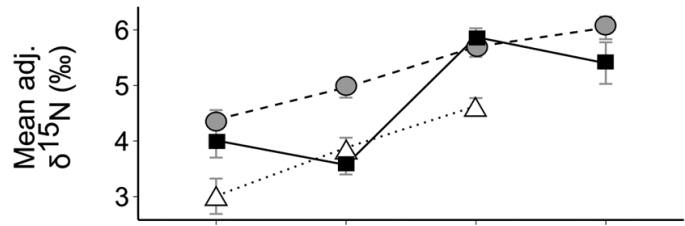

e)

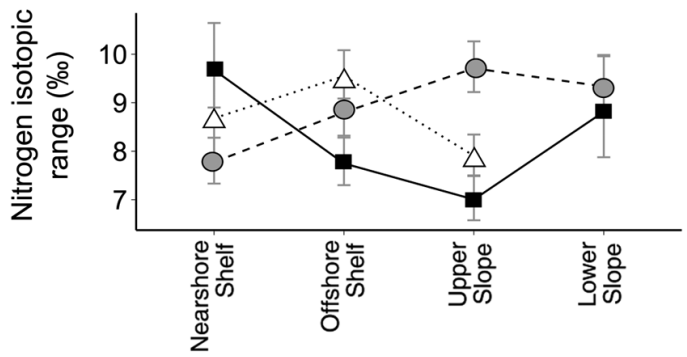

Fig. 3. Community-level isotopic niche metrics for each longitudinal region across vertical water mass assemblages: (a) niche region size, (b) mean ${ }^{13} \mathrm{C}$ enrichment from a pelagic baseline $\left(\Delta^{13} \mathrm{C}_{\mathrm{pel}}\right)$, (c) carbon range of the niche region, (d) mean baseline-adjusted $\delta^{15} \mathrm{~N}$, and (e) nitrogen range of the niche region. Points: mode of the posterior distribution for each niche metric, created with 10000 iterative calculations; whiskers: 95\% credible intervals; lines: trends among discrete water mass assemblages (not a continuous scale). The lower slope assemblage does not occur in the Amundsen Gulf. Raw values calculated for all community-level niche metrics are in Supplement 2 at www.int-res.com/articles/ suppl/m594p001_supp2.pdf

increased from west to east in all but the deepest vertical water mass assemblage (Fig. $3 \mathrm{a}-\mathrm{C}$; also see Table S2-1 in Supplement 2). When community-level niche structure was scaled down to the functional group level, the eastward increases in community- level niche region size, mean $\Delta^{13} \mathrm{C}_{\mathrm{pel}}$, and carbon isotopic range at the community-level were associated with increasing isotopic separation between benthic and pelagic functional groups (Table 4). Within each water mass assemblage, benthic functional groups shifted to higher $\Delta{ }^{13} C_{\text {pel }}$ values in the AG relative to the western or central CBS (aside from the lower slope which is absent in the $A_{G}$; Fig. 4). Consequently, a clear distinction between the mean $\Delta \Delta^{13} \mathrm{C}_{\text {pel }}$ of pelagic and benthic functional groups was evident (up to $5.7 \%$ ) and increased from west to east (Table 4, Fig. 4). Pelagic herbivores and carnivores exhibited the lowest $\Delta^{13} C_{\text {pel }}$ values in all water mass assemblages (Fig. 4). Benthopelagic carnivores generally had $\Delta^{13} \mathrm{C}_{\mathrm{pel}}$ values lower than those of benthic carnivores, but higher than those of pelagic carnivores. These same trends of increasing $\Delta \Delta^{13} \mathrm{C}_{\mathrm{pel}}$ from west to east were observed for many individual benthic taxa (Fig. S2-1 in Supplement 2). The most variable within- and among-region $\Delta^{13} \mathrm{C}_{\mathrm{pel}}$ values were exhibited by the facultative benthic surface deposit feeders/suspension feeders (SDF/SF) and benthic SDF, which also generally had larger niche regions and wider carbon isotopic ranges than did most other functional groups in the offshore shelf and upper slope assemblages (see Supplement 2).

Mean community-level $\delta^{15} \mathrm{~N}$ was generally highest in the central CBS, whereas nitrogen isotopic range was highest in the central CBS for the upper and lower slope assemblages only (Fig. 3d,e). Wide community-level nitrogen isotopic ranges in the central CBS (Fig. 3e) were associated with the

Table 4. Mean difference between $\Delta^{13} \mathrm{C}_{\text {pel }}$ values of pelagic and benthic functional groups, showing an increasing difference from west to east, and from the nearshore shelf to the upper slope water mass assemblage. CBS: Canadian Beaufort Sea

\begin{tabular}{|llc|}
\hline $\begin{array}{l}\text { Water mass } \\
\text { assemblage }\end{array}$ & Region & $\begin{array}{c}\text { Difference } \\
(\%)\end{array}$ \\
\hline Nearshore shelf & Western CBS & 2.30 \\
& Central CBS & 3.01 \\
Offshore shelf & Western CBS & 3.88 \\
& Central CBS & 2.86 \\
& Amundsen Gulf & 4.28 \\
Upper slope & Western CBS & 4.78 \\
& Central CBS & 4.78 \\
Lower slope & Amundsen Gulf & 5.65 \\
& Western CBS & 4.15 \\
& Central CBS & 3.48 \\
\hline
\end{tabular}


widest ranges of mean baseline-adjusted $\delta^{15} \mathrm{~N}$ values among functional groups (Fig. 5). Nitrogen isotopic range for any single functional group, however, did not follow obvious regional trends (Supplement 2).
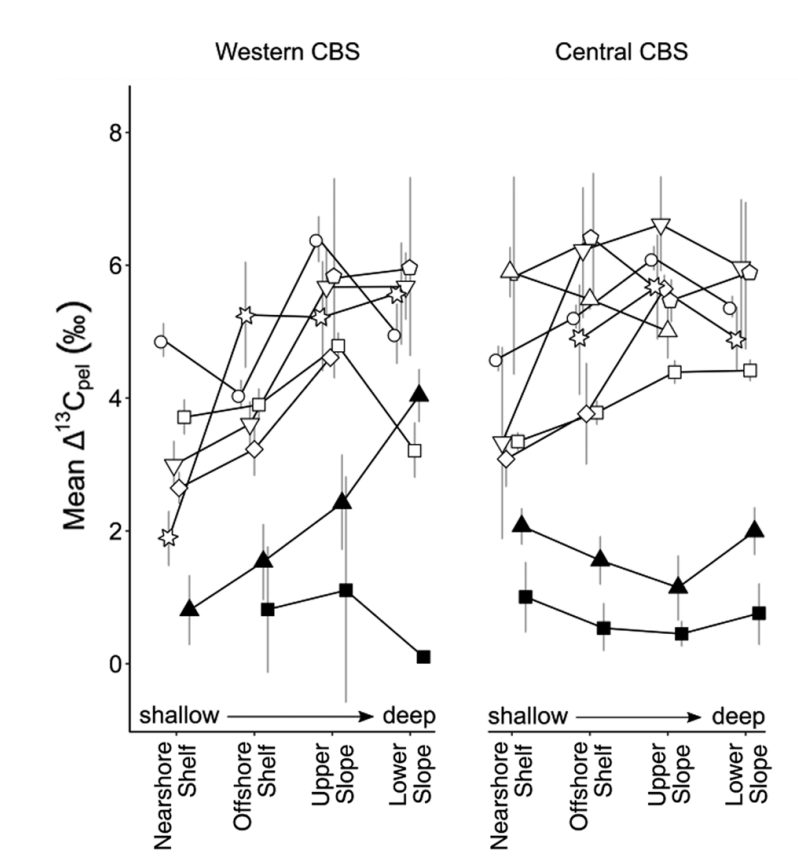

\section{Influence of vertical water mass structure}

Water mass assemblage had an effect on community-level trophic structure. Within any given region, the upper slope assemblage exhibited the highest

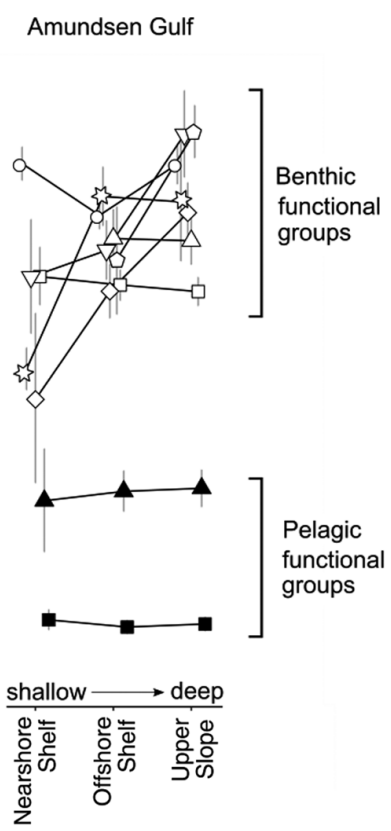
$\square$ Benthopelagic carnivore
- Benthic carnivore
$\triangle$ Benthic SS carnivore
$\diamond$ Benthic SF
$\nabla$ Benthic SDF/SF
is Benthic SDF
$\checkmark$ Benthic SSDF

Fig. 4. Mean ${ }^{13} \mathrm{C}$ enrichment from a pelagic baseline $\left(\Delta^{13} \mathrm{C}_{\text {pel }}\right)$ for functional groups (see Table 1 for abbreviations) across water mass assemblages, within each longitudinal region (CBS: Canadian Beaufort Sea). Points: modes of the posterior distributions, created with 10000 iterative calculations; whiskers: 95\% credible intervals; lines: trends among discrete water mass assemblages (not a continuous scale). A clear and increasing divergence between benthic (white) and pelagic (black) functional groups along the $\Delta^{13} \mathrm{C}_{\mathrm{pel}}$ continuum suggests that benthic-pelagic coupling weakened from west to east and from the nearshore shelf to the upper slope
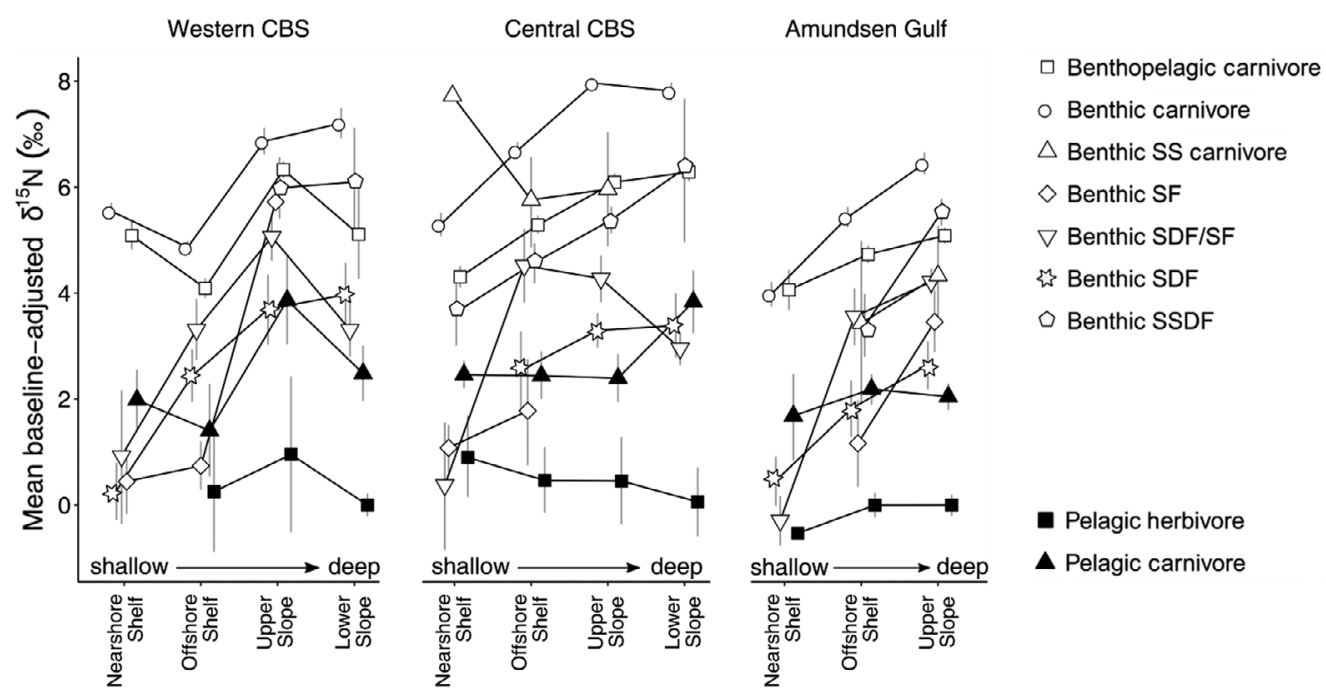

Fig. 5. Mean baseline-adjusted $\delta^{15} \mathrm{~N}$ for functional groups (see Table 1 for abbreviations) across water mass assemblages, within each longitudinal region (CBS: Canadian Beaufort Sea). Points: modes of the posterior distributions, created with 10000 iterative calculations; whiskers: $95 \%$ credible intervals; lines: trends among discrete water mass assemblages (not a continuous scale). Within regions, mean $\delta^{15} \mathrm{~N}$ for most functional groups increased with depth. The central CBS generally exhibited the widest among-group spread of mean $\delta^{15} \mathrm{~N}$ values 
community-level mean $\Delta{ }^{13} \mathrm{C}_{\text {pel }}$, and carbon isotopic range in almost all cases, whereas the nearshore shelf assemblage exhibited the lowest values for these same niche metrics in most cases (Fig. 3a-c). Mean community baseline-adjusted $\delta^{15} \mathrm{~N}$ increased from the shallowest to the deepest water mass assemblage, whereas there was no consistent trend in nitrogen isotopic range across water mass assemblages (Fig. 3d,e).

Scaling niche metrics down to the functional group level revealed that within any given region, the mean $\Delta^{13} \mathrm{C}_{\text {pel }}$ of benthic functional groups generally increased from the nearshore shelf to the upper slope (Fig. 4). Consequently, benthic functional groups became increasingly separated from pelagic functional groups along the $\delta^{13} \mathrm{C}$ continuum along an onshoreoffshore gradient. Benthic carnivores had the highest mean $\delta^{15} \mathrm{~N}$ in almost every community, whereas pelagic herbivores almost always had the lowest (Fig. 5). The distance between benthic carnivore and pelagic herbivore $\delta^{15} \mathrm{~N}$ increased from the shallowest water mass assemblage to the deepest (Fig. 5). No clear trends emerged across water mass assemblages for functional group niche size, carbon isotopic range, or nitrogen isotopic range (Supplement 2).

\section{Association between trophic structure and proxies for pelagic OM input}

Community-level mean $\Delta^{13} \mathrm{C}_{\text {pel }}$ and carbon isotopic range were significantly positively related to \% sediment $O M$ content (Fig. 6a,c: $\Delta^{13} \mathrm{C}_{\mathrm{pel}}: F_{1,9}=28.06, \mathrm{r}^{2}=$ $0.78, \mathrm{p}<0.01$; carbon isotopic range: $F_{1,9}=9.44, \mathrm{r}^{2}=$ 0.54, $\mathrm{p}=0.02$ ). Community-level mean $\Delta^{13} \mathrm{C}_{\mathrm{pel}}$ and carbon isotopic range were also significantly positively related to total $\mathrm{chl} a$ at the subsurface chlorophyll maximum depth (Fig. 6b,d: $\Delta^{13} \mathrm{C}_{\text {pel }}: F_{1,8}=36.93$, $\mathrm{r}^{2}=0.82, \mathrm{p}<0.01$; carbon isotopic range: $F_{1,8}=9.55$, $\left.\mathrm{r}^{2}=0.54, \mathrm{p}=0.01\right)$. Mean community-level $\delta^{15} \mathrm{~N}$ was significantly negatively related to sedimentary chl $a$ : phaeopigments $\left(F_{1,8}=13.67, \mathrm{r}^{2}=0.60, \mathrm{p}<0.01\right)$. There were no other significant relationships between community isotopic niche metrics and proxies for availability of pelagic production to the benthos. a)
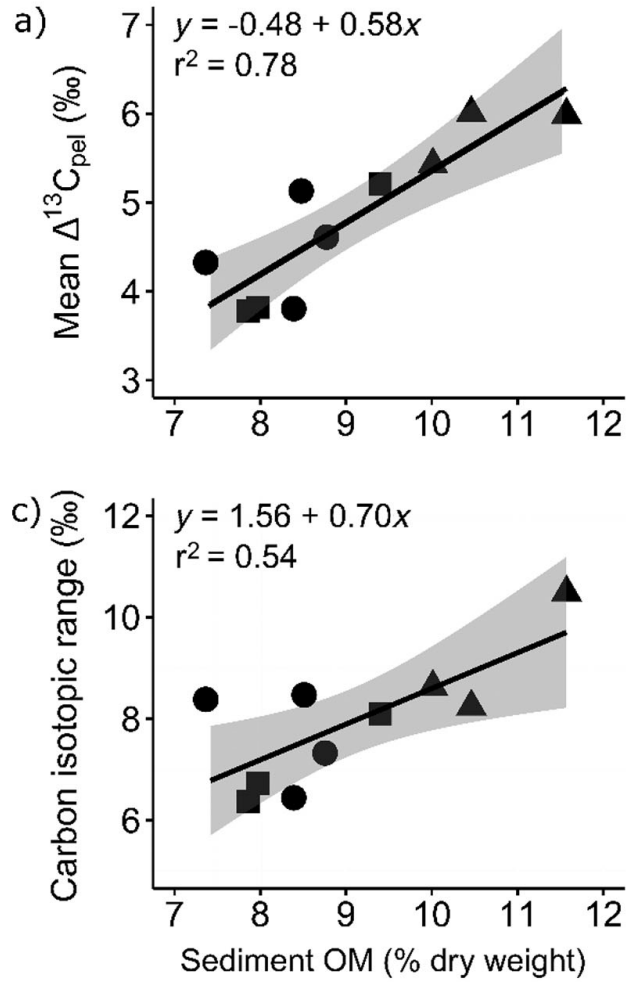

b)

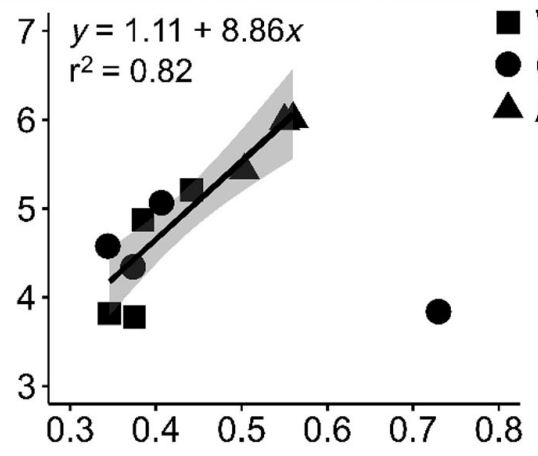

d) 1

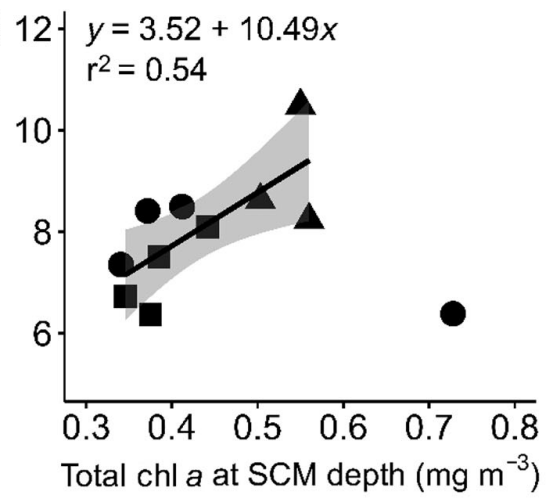

Western CBS Central CBS

Amundsen Gulf

Fig. 6. Linear regressions between mean ${ }^{13} \mathrm{C}$ enrichment from a pelagic baseline $\left(\Delta^{13} \mathrm{C}_{\mathrm{pel}}\right)$ and (a) sediment organic matter $(\mathrm{OM})$ and (b) total chl $a$ at the subsurface chlorophyll maximum (SCM) depth, as well as linear regressions between carbon isotopic range of the niche region and (c) sediment OM and (d) total chl $a$ at the $\mathrm{SCM}$ depth. The isotopic niche metrics $\Delta^{13} \mathrm{C}_{\mathrm{pel}}$ and carbon range were calculated at the community level for longitudinal regions, within water mass assemblages $(\mathrm{n}=11$ communities). Results presented for (b) and (d) do not include consideration of the outlier (representing 2 nearshore sites in the Central CBS). All relationships were significant $(\mathrm{p}<0.05)$. CBS: Canadian Beaufort Sea 
Sediment mean grain size was significantly positively correlated with sediment chl a (Pearson correlation, $r=0.62$, df $=47, \mathrm{p}<0.01$ ), sediment $\mathrm{C}: \mathrm{N}$ ratio (Pearson correlation, $\mathrm{r}=0.38$, $\mathrm{df}=48, \mathrm{p}=$ 0.01), and sediment chl a:phaeopigments (Pearson correlation, $\mathrm{r}=0.38$, df $=48, \mathrm{p}<0.01$ ). Sediment $\%$ OM content was positively, but weakly, correlated to total chl $a$ at the subsurface chlorophyll maximum depth (Pearson correlation, $\mathrm{r}=0.38$, $\mathrm{df}=$ $37, \mathrm{p}=0.02)$. There were no other significant associations between pairwise combinations of proxies for the availability of pelagic production to the benthos. Two nearshore sites in the central CBS (KUG 01 and DAL 02) were identified as outliers with higher than usual total chl $a$ at the subsurface chlorophyll maximum depth and were removed from the analysis.

\section{DISCUSSION}

Spatial patterns of OM input and water mass structure influenced trophic connectivity between benthic and pelagic functional groups in an Arctic marine system up to $1000 \mathrm{~m}$ downslope, but not as expected. Benthic-pelagic trophic coupling was generally highest in shallow habitats, as predicted, but not in habitats underlying high primary production or nutrientrich water masses (e.g. Tamelander et al. 2006, Iken et al. 2010). Instead, the strength of benthic-pelagic trophic coupling followed a 2-dimensional regional gradient, which we suggest is likely established by physical and biochemical processes controlling the availability of OM to the benthos. First, benthicpelagic trophic coupling weakened across an alongshore gradient of OM inputs and sinking flux regimes. Coupling was weakest in the eastern study region where pelagic grazing is known to be high, intermediate in the central study region dominated by riverine inputs of terrestrial carbon, and strongest in the western study region where carbon export to the benthos is relatively higher. Second, an onshoreoffshore gradient in benthic-pelagic trophic coupling was linked to the vertical water mass assemblage. The weakest benthic-pelagic trophic coupling consistently occurred in upper slope habitats. Here, benthos underlie the transition between Pacific- and Atlantic-origin waters, where much of the organic carbon may be transformed or intercepted by aggregations of zooplankton and fish (e.g. Crawford et al. 2012), and where intensified current velocities enhance OM re-suspension and heterogeneity (Forest et al. 2015).

\section{Influence of longitudinal gradient in OM inputs}

\author{
AG: pelagic retention of autochthonous POC
}

At the community level, eastward increases in mean enrichment from a pelagic baseline $\left(\Delta^{13} \mathrm{C}_{\text {pel }}\right)$ and wider carbon isotopic ranges were positively related to 2 proxies for the availability of pelagic POC to benthos: sediment OM content and phytoplankton biomass at the subsurface chlorophyll maximum depth. Both proxies were highest in the AG. If higher phytoplankton biomass resulted in a greater availability of fresh phytodetritus to the benthos, benthic suspension and deposit feeders would be expected to exhibit $\delta^{13} \mathrm{C}$ values more similar to those of pelagic grazers (i.e. low mean $\Delta^{13} \mathrm{C}_{\text {pel }}$ ). Such a phenomenon has been linked to tight benthic-pelagic coupling in other Arctic regions with high pelagic production (e.g. marginal ice zone, Tamelander et al. 2006; Chukchi Sea, McTigue \& Dunton 2014). Instead, we observed that benthic groups underlying sites with high algal biomass in the AG exhibited greater $\Delta{ }^{13} \mathrm{C}_{\text {pel }}$ than did their counterparts in the central and western CBS, regardless of vertical water mass assemblage. Consequently, pelagic and benthic functional groups became increasingly separated in isotopic space from west to east. Isotopic separation at the functional group level was associated with larger niche regions, higher mean $\Delta^{13} \mathrm{C}_{\text {pel }}$, and wider carbon isotopic ranges at the whole community level. This finding contrasts with our prediction that areas with high algal biomass would have tighter linkages between benthic and pelagic food webs. However, results are consistent with sediment trap-based estimates by Forest et al. (2010) that indicated 70 to $90 \%$ of autochthonous POC in the AG is retained in the upper $100 \mathrm{~m}$ of the water column. Sites with high POC deposition rates are often characterized by finegrained sediment that has high OM content, high chl $a$, and low C:N ratios (Cooper et al. 2015). The weak or insignificant correlations between these deposition proxies at our sampling sites, along with the unusual positive association between coarse-grained sediments and high sedimentary chl $a$, suggest benthic POC deposition is low in the region of high algal biomass. Instead, the high sediment OM in the AG may represent a pool of low-quality food for the benthos, as suggested by Magen et al. (2010) and Roy et al. (2014).

Retention of new production by the pelagic community would explain the ${ }^{13} \mathrm{C}$ enrichment of benthic relative to pelagic functional groups in the AG and the resulting wider community-level carbon isotopic 
ranges. Benthic consumers have to rely on a more diverse array of alternative carbon sources where fresh phytodetritus is limited (McTigue \& Dunton 2014, Roy et al. 2015, Bell et al. 2016), increasing the difference between benthic and pelagic $\delta^{13} \mathrm{C}$. Extensively decomposed OM can become enriched in ${ }^{13} \mathrm{C}$ via microbial remineralization, and the bacteria and extracellular matrices themselves may be additional food sources for benthic organisms that rely on accumulated sedimentary OM (Lovvorn et al. 2005, McTigue \& Dunton 2014, North et al. 2014). Bacterial products have higher $\delta^{13} \mathrm{C}$ and are a more biologically accessible food than bulk sediments (Decho 1990, Lovvorn et al. 2005). Bacterial biomass and recycled OM may be especially important for maintaining high latitude macroinvertebrate communities when labile marine-derived POC is scarce (e.g. McTigue \& Dunton 2014, Bell et al. 2016).

Ice algae are an additional source of pelagicderived POC. Ice algae can sink fast (Michel et al. 1997), such that they escape grazing in the upper water column and are delivered to the seafloor relatively intact, where they can then be consumed by benthic invertebrates (McMahon et al. 2006, Renaud et al. 2007b, Boetius et al. 2013). Benthic deposit and suspension feeders collected in the AG for this study and by Roy et al. (2015) were enriched in ${ }^{13} \mathrm{C}$ relative to pelagic POC by 3 to $7.5 \%$ on average (C. Michel unpubl. data). These data are consistent with a potential significant contribution of ice algae to benthic consumer diets, as ice algae can have $\delta^{13} \mathrm{C}>5 \%$ higher than that of pelagic POC when ice algal biomass is high (Gradinger et al. 2009). Assimilation of ice algal carbon appears most significant for deposit feeders (McMahon et al. 2006, Søreide et al. 2013, North et al. 2014), and may be a source of otherwise limited essential fatty acids where pelagic and terrestrial carbon inputs are minimal (Sun et al. 2007). However, benthic community structure and biomass at high latitudes are more strongly associated with long-term indices of accumulated sedimentary OM than with seasonal pulses of phytodetritus (Renaud et al. 2008, Smith et al. 2012). Similarly, experimental and observational evidence suggest the stable isotope values of benthic consumers do not respond strongly to short-term variability in primary production or sea ice deposition (e.g. Kędra et al. 2012, North et al. 2014). Although sedimentary OM content was relatively high in the AG, the lack of correlation with sedimentary chl $a$ and chl a:phaeopigments suggests that the OM was neither fresh nor conclusively algal-derived (Morata et al. 2011). Increased export of ice algae and phytoplankton at the mar- ginal ice edge may represent a seasonal period of intensified benthic-pelagic coupling (Tamelander et al. 2006, Renaud et al. 2008). However, it seems most likely that higher $\Delta^{13} \mathrm{C}_{\mathrm{pel}}$ at both the community and functional group levels reflect lower average pelagic POC export to the benthos compared to other regions in this study.

The impact of long-term changes in food supply associated with sea ice loss is still unclear. Increased primary production during a longer ice-free season may promote intensified pelagic herbivory that reduces benthic food supply in some areas (Forest et al. 2010, Wassmann \& Reigstad 2011). The AG may exemplify such a scenario, and provide an opportunity to examine the carbon sources that sustain benthic communities in the absence of substantial pelagic POC inputs.

\section{Central CBS: influence of terrestrial carbon}

Intermediate values of community-level niche region size, mean $\Delta \Delta^{13} \mathrm{C}_{\mathrm{pel}}$, and carbon isotopic range observed in the central CBS can be linked to a strong terrestrial influence from the Mackenzie River. Coriolis forcings usually drive the freshwater and sediment plume eastward, such that communities within the central CBS are exposed to high inputs of terrestrial OM $(>50 \%$ of the bulk sediment pool as deep as $1000 \mathrm{~m}_{i}$ Magen et al. 2010). Sediment trap data from Juul-Pedersen et al. (2008) demonstrated that POC sinking fluxes are relatively high under the Mackenzie River plume. The composition of the sinking organic material varied seasonally, but included both refractory riverine carbon and marine phytoplankton, and contained higher proportions of zooplankton fecal pellets in summer due to higher grazing activity by copepods (Juul-Pedersen et al. 2008). Recent studies have demonstrated that terrestrial inputs can indirectly support a high relative benthic biomass (Dunton et al. 2006, 2012, Roy et al. 2015), likely by acting as favourable substrate for microbial communities that increase sediment lability (Bell et al. 2016). We propose that benthic-pelagic trophic coupling is dampened in terrestrially dominated systems due to a combination of high benthic reliance on microbially transformed terrestrial OM (Dunton et al. 2006) and lower pelagic primary production in sediment-laden waters (Carmack et al. 2004). Greater consumption of transformed terrestrial OM is consistent with higher mean community $\delta^{15} \mathrm{~N}$ and nitrogen isotopic range in this region compared to the western CBS and AG, as extensive microbial processing of sedimentary $\mathrm{OM}$ 
can lengthen Arctic benthic marine food webs (Dunton et al. 2006, Iken et al. 2010, Bell et al. 2016). Concurrently, benthic-pelagic coupling in the central CBS may be higher than that in the AG due to increased pelagic sinking fluxes in the summer and fall under the influence of the Mackenzie River plume in the central CBS (Juul-Pedersen et al. 2008).

West of the Mackenzie River: lower influence of terrestrial OM and grazing

The western CBS communities exhibited the smallest niche region sizes, lowest mean $\Delta^{13} \mathrm{C}_{\text {pel }}$ values, and narrowest carbon isotopic ranges of any region examined. When niche metrics were examined at the functional group level, benthic and pelagic groups in the western CBS were closer to each other along the ${ }^{13} \mathrm{C}$ continuum than in the other 2 regions. Together, these findings suggest that the western study region exhibited the tightest benthic-pelagic trophic coupling. However, benthic-pelagic trophic coupling in the western CBS may still be weak compared to other Arctic areas, where most benthic fauna have $\delta^{13} \mathrm{C}$ within $5 \%$ of Calanus spp. (e.g. North Water Polynya, Hobson et al. 1995; Barents Sea marginal ice zone, Tamelander et al. 2006; Chukchi Sea, McTigue \& Dunton 2014). Moreover, benthic biomass on the shelf remains relatively low across most of the study region compared to, for example, the Chukchi shelf (<50 $\mathrm{g} \mathrm{m}^{-2}$ for macrobenthos; Dunton et al. 2005, Conlan et al. 2013)

Our results appear to be an extension of a larger gradient of weakening benthic-pelagic coupling from west to east along the entire Beaufort Sea coast (Dunton et al. 1989, 2005, Bell et al. 2016). Benthic consumers west of the Colville River are under a stronger influence of nutrient-rich Pacific waters and make greater use of marine-derived POC, coincident with lower $\delta^{13} \mathrm{C}$ and shorter food web lengths (Divine et al. 2015, Bell et al. 2016). East of the Colville River, longer benthic food webs have been attributed to the increasing influence of terrestrial OM (0.5 to 1.7 trophic levels longer; Bell et al. 2016). Macrobenthic biomass on the shelf also generally declines eastward from as high as $~ 80 \mathrm{~g} \mathrm{~m}^{-2}$ near Point Barrow, Alaska, to as low as $0.01 \mathrm{~g} \mathrm{~m}^{-2}$ near the mouth of the Mackenzie River (Dunton et al. 2005). Benthic-pelagic trophic coupling therefore appears to continue to weaken along an eastward, although not necessarily linear, gradient of increasing terrestrial OM influence and weakening Pacific influence. Since terrestrial influence is strongest in the central CBS, the weakest benthic-pelagic trophic coupling observed in the AG in this study is probably a consequence of intense pelagic grazing rather than an extension of the same terrestrially influenced gradient.

\section{Influence of vertical water mass structure}

Evidence for differing benthic food web and community structure underneath adjacent surficial water masses is mounting for high latitude systems (e.g. Carroll et al. 2008, Iken et al. 2010, Brandt et al. 2014). In contrast, studies on how vertical water mass distributions affect benthic-pelagic coupling are lacking. In this study, community-level niche region size and carbon-associated isotopic niche metrics increased from the nearshore shelf to the upper slope water mass assemblage, and were associated with a clear divergence between benthic and pelagic functional groups along the $\Delta^{13} C_{\text {pel }}$ continuum. These patterns suggest greater trophic diversity and lower benthic-pelagic trophic coupling in the upper slope assemblage compared to other water mass assemblages. Since the weakest trophic coupling was not observed in the deeper lower slope assemblage, our work does not support depth as the only explanation. Rather, biological and physical processes associated with subsurface water mass boundaries likely interact with depth to best explain spatial trends in benthic-pelagic trophic connectivity.

Several physical and biological features of the vertically stacked water masses are unique to the study area. Following the spring phytoplankton bloom, nitrate is quickly depleted in Arctic Ocean surface waters (e.g. Carmack et al. 2004, Ardyna et al. 2013). The chlorophyll maximum layer then becomes deeper, often occurring at $\sim 40$ to $60 \mathrm{~m}$ depths during summer on the CBS and AG shelves. Benthos on the shelf thus have greater access to relatively fresh and untransformed marine OM compared to deeper communities. The consumption of fresh phytodetritus is reflected in lower mean $\delta^{15} \mathrm{~N}$ values in the shelf versus slope habitats (Divine et al. 2015, Bell et al. 2016, this study). Over deeper waters in the western Arctic, the subsurface chlorophyll maximum approximately corresponds with the transition to the Pacific Halocline. Pelagic POC, therefore, has a relatively short distance to sink to reach the thermohalocline transition to Atlantic water $\sim 200 \mathrm{~m}$ below. A substantial proportion of sinking POC may become entrained near the thermohalocline and not reach the seafloor (Forest et al. 2015). Large aggregations of zooplankton are closely associated with the shelf-break near the transition be- 
tween the Pacific and Atlantic water masses (Crawford et al. 2012, Smoot \& Hopcroft 2017) and in turn may explain high Arctic cod densities in the same layer (Majewski et al. 2017). Large aggregations of benthopelagic fish might be expected to actively transfer some OM from the pelagic zone to the benthos (Stasko et al. 2016), but in this study were instead associated with habitats with lower benthic-pelagic coupling. Deep zooplankton aggregations may have grazed substantial fractions of the above-produced POC, limiting POC availability at the seafloor for demersal fauna. Indeed, Majewski et al. (2017) speculated that Arctic cod may out-compete benthic fishes in the upper slope habitat where alternative benthic food sources are limited. Our results support this hypothesis. High carbon interception and transformation in the upper Atlantic Layer (Crawford et al. 2012, Forest et al. 2015) may explain the largest niche size, largest carbon isotopic ranges, and high mean $\delta^{15} \mathrm{~N}$ values observed for the upper slope community. POC consumption by pelagic zooplankton and the microbial loop commonly limit benthic food supply in the global ocean, including high latitudes (Grebmeier \& Barry 1991), but biological interception by deep aggregations of higher-trophic fauna is neither well documented nor well understood.

The upper slope community occupies a physically dynamic habitat at the shelf-break. Habitat heterogeneity associated with steep bathymetry and complex current dynamics (e.g. Forest et al. 2015) may have additionally contributed to the wider carbon isotopic ranges and larger niche sizes observed in the upper slope simply by increasing the diversity of benthic resources available. In particular, high current velocities and seasonal flow reversals in the shelfbreak jet enhance the transport of re-suspended sediments and distinct water types between the shelf and basin (e.g. Nikolopoulos et al. 2009, Forest et al. 2015). The high carbon isotopic ranges observed for flexibly feeding surface deposit and suspension feeders in the upper slope support the notion that food availability was variable (Roy et al. 2015).

We cannot exclude the possibility that microphytobenthos were an additional uncharacterized OM source for nearshore shelf communities (e.g. McTigue \& Dunton 2014). The highest sediment chl a measurements in this study were observed at sampling sites $\leq 40 \mathrm{~m}$ depths, but we did not have the data to estimate the proportion of chl a attributable to pelagic versus benthic algae. It is conceivable that the low $\delta^{13} \mathrm{C}$ values of benthos in the nearshore shelf were partially attributable to the assimilation of benthic microalgal carbon (Oxtoby et al. 2016).

\section{Regional context and conclusions}

When placed in a larger regional context, our data extend the understanding of variation in benthic trophic structure and benthic-pelagic trophic coupling along the western Arctic coast of North America. Our data, combined with those of others, show that complex spatial patterns in benthic-pelagic coupling are clearly linked to the local OM inputs and flux dynamics that control food supply to the benthos. Near Point Barrow, Alaska, the stable isotope values of benthic consumers on the shelf have been shown to reflect a strong reliance on marine-derived OM, despite evidence for substantial terrestrial inputs from small coastal rivers and erosion (Dunton et al. 2006, Divine et al. 2015). The influence of nutrientladen Pacific waters that enter from the nearby Chukchi Sea and comparatively low pelagic grazing are considered responsible for the tight benthicpelagic trophic coupling in the western American Beaufort Sea (Dunton et al. 2005, Divine et al. 2015). Further east towards the Colville River and Camden Bay, benthic consumers as deep as $1000 \mathrm{~m}$ have greater reliance on terrestrially derived carbon, which is strongest near the Mackenzie River outflow (Dunton et al. 2006, Divine et al. 2015, Bell et al. 2016). Our results suggest that terrestrial OM continues to play a role in decoupling pelagic and benthic food webs across the central CBS shelf and slope, likely because bacterially transformed terrestrial matter is a labile and attractive benthic food source in areas with limited marine POC (Bell et al. 2016). Finally, benthic-pelagic trophic coupling is weakest in the AG, where extensive grazing by pelagic consumers limits the vertical flux of marine POC despite relatively high primary production (Forest et al. 2010, this study). In response, benthic taxa have higher ${ }^{13} \mathrm{C}$ enrichment relative to pelagic taxa (this study), benthic carbon remineralization is low (Darnis et al. 2012), epibenthic biomass is low and spatial heterogeneity in community composition is high (Roy et al. 2014), and benthic primary consumers likely rely more heavily on transformed sedimentary OM (Roy et al. 2015, this study). Across the entire region, we found the difference in carbon use between benthic and pelagic functional groups was largest near the shelf-break on the upper slope, directly under the transition between Pacific- and Atlantic-origin waters. Here, benthic food supply was likely limited by biological interception but, perhaps, diversified by carbon transformation and sediment re-suspension.

Together with previous work, this study establishes that gradients in food web structure do not necessar- 
ily follow water depth or obvious indicators of pelagic productivity. Rather, Arctic benthic-pelagic trophic coupling is more closely linked to biological and physical processes in the water column that govern OM availability to the benthos. Arctic benthic communities that are at least partially sustained by microbially processed terrestrial OM may be relatively less sensitive to changes in sea ice phenology than those that rely predominantly on overlying pelagic and/or ice algal production. However, the benthic response to changes at the ocean surface may be mediated by subsurface hydrography and by the food web in the upper water column that intercepts sinking POC, and is in turn influenced by water mass boundaries.

Acknowledgements. We are grateful to the Inuvialuit Game Council for their valuable input and continued support of the Beaufort Sea Marine Fishes Project. Many thanks to the crew and staff of Frosti Fishing for logistical support; S. MacPhee, S. Atchison, L. de Montety, and W. Walkusz for taxonomy and data management; A. Niemi, J. Eert, and L. de Montety for primary production, oceanography, and sedimentary data; J. Pearson and K. Mitchell for laboratory assistance; the Department of Arctic and Marine Biology at UiT - the Arctic University of Norway for hosting A.D.S. during project collaboration; and 5 anonymous reviewers for helpful comments. Funding was provided by the Fisheries Joint Management Committee (Inuvik, NT), Aboriginal Affairs and Northern Development Canada (BREA), Natural Resources Canada (Environmental Research Fund, Program of Energy Research and Development), and internal Fisheries and Oceans Canada sources. Additional support was provided by an NSERC Canada Graduate Scholarship and Michael Smith Foreign Study Supplement to A.D.S., NSERC Discovery grants to M.P. and H.S., and internal support from UiT to B.A.B.

\section{LITERATURE CITED}

Ardyna M, Babin M, Gosselin M, Devred E, Bélanger S, Matsuoka A, Tremblay JÉ (2013) Parameterization of vertical chlorophyll $a$ in the Arctic Ocean: impact of the subsurface chlorophyll maximum on regional, seasonal, and annual primary production estimates. Biogeosciences 10:4383-4404

Barber DG, Asplin MG, Gratton Y, Lukovich JV, Galley RJ, Raddatz RL, Leitch D (2010) The International Polar Year (IPY) Circumpolar Flaw Lead (CFL) system study: overview and the physical system. Atmos-ocean 48:225-243

Belkin IM, Cornillon PC, Sherman K (2009) Fronts in large marine ecosystems. Prog Oceanogr 81:223-236

* Bell LE, Bluhm BA, Iken K (2016) Influence of terrestrial organic matter in marine food webs of the Beaufort Sea shelf and slope. Mar Ecol Prog Ser 550:1-24

Boetius A, Albrecht A, Bakker K, Bienhold C and others (2013) Export of algal biomass from the melting Arctic sea ice. Science 339:1430-1432

Bost CA, Cotté C, Bailleul F, Cherel Y and others (2009) The importance of oceanographic fronts to marine birds and mammals of the southern oceans. J Mar Syst 78:363-376

* Brandt A, Vanreusel A, Bracher A, Hoppe CJM and others (2014) Are boundary conditions in surface productivity at the Southern Polar Front reflected in benthic activity? Deep Sea Res II 108:51-59

Carmack EC, Macdonald RW (2002) Oceanography of the Canadian Shelf of the Beaufort Sea: a setting for marine life. Arctic 55:29-45

* Carmack EC, Macdonald RW, Jasper S (2004) Phytoplankton productivity on the Canadian Shelf of the Beaufort Sea. Mar Ecol Prog Ser 277:37-50

* Carroll ML, Denisenko SG, Renaud PE, Ambrose WG Jr (2008) Benthic infauna of the seasonally ice-covered western Barents Sea: patterns and relationships to environmental forcing. Deep Sea Res II 55:2340-2351

Clark ID, Fritz P (1997) Environmental isotopes in hydrogeology. CRC Press, Boca Raton, FL

Clarke KR, Warwick RM (1998) A taxonomic distinctness index and its statistical properties. J Appl Ecol 35: 523-531

Conlan K, Hendrycks E, Aitken A, Williams B, Blasco S, Crawford E (2013) Macrofaunal biomass distribution on the Canadian Beaufort Shelf. J Mar Syst 127:76-87

Connelly TA, Diebel D, Parrish CC (2014) Trophic interactions in the benthic boundary layer of the Beaufort Sea shelf, Arctic Ocean: combining bulk stable isotope and fatty acid signatures. Prog Oceanogr 120:79-92

* Cooper LW, Savvichev AS, Grebmeier JM (2015) Abundance and production rates of heterotrophic bacterioplankton in the context of sediment and water column processes in the Chukchi Sea. Oceanography (Wash DC) 28:84-99

Craig H (1957) Isotopic standards for carbon and oxygen and correction factors for mass-spectrometric analysis of carbon dioxide. Geochim Cosmochim Acta 12:133-149

* Crawford RE, Vagle S, Carmack EC (2012) Water mass and bathymetric characteristics of polar cod habitat along the continental shelf and slope of the Beaufort and Chukchi seas. Polar Biol 35:179-190

* Darnis G, Robert D, Pomerleau C, Link H and others (2012) Current state and trends in Canadian Arctic marine ecosystems: II. Heterotrophic food web, pelagic-benthic coupling, and biodiversity. Clim Change 115:179-205

Decho AW (1990) Microbial exoploymer secretions in ocean environments: their role(s) in food webs and marine processes. Oceanogr Mar Biol Annu Rev 28:73-153

* Divine LM, Iken K, Bluhm BA (2015) Regional benthic food web structure on the Alaska Beaufort Sea shelf. Mar Ecol Prog Ser 531:15-32

* Dunton KH, Saupe SM, Golikov AN, Schell DM, Schonberg SV (1989) Trophic relationships and isotopic gradients among arctic and subarctic marine fauna. Mar Ecol Prog Ser 56:89-97

* Dunton KH, Goodall JL, Schonberg SV, Grebmeier JM, Maidment DR (2005) Multi-decadal synthesis of benthic-pelagic coupling in the western arctic: role of crossshelf advective processes. Deep Sea Res II 52:3462-3477

* Dunton KH, Weingartner T, Carmack EC (2006) The nearshore western Beaufort Sea ecosystem: circulation and importance of terrestrial carbon in arctic coastal food webs. Prog Oceanogr 71:362-378

Wunton KH, Schonberg SV, Cooper LW (2012) Food web structure of the Alaskan nearshore shelf and estuarine lagoons of the Beaufort Sea. Estuaries Coasts 35:416-435

Eert J, Meisterhans G, Michel C, Niemi A, Reist J, Williams 
WJ (2015) Physical, chemical and biological oceanographic data from the Beaufort Regional Environmental Assessment: Marine Fishes Project, August-September 2012. Can Data Rep Hydrogr Ocean Sci 197. Fisheries and Oceans Canada, Ottawa

Fagan KA, Koops MA, Arts MT, Power M (2011) Assessing the utility of $\mathrm{C}: \mathrm{N}$ ratios for predicting lipid content in fishes. Can J Fish Aquat Sci 68:374-385

Feder HM, Iken K, Blanchard AL, Jewett SC, Schonberg S (2011) Benthic food web structure in the southeastern Chukchi Sea: an assessment using $\delta^{13} \mathrm{C}$ and $\delta^{15} \mathrm{~N}$ analyses. Polar Biol 34:521-532

Forest A, Bélanger S, Sampei M, Sasaki H, Lalande C, Fortier L (2010) Three-year assessment of particulate organic carbon fluxes in Amundsen Gulf (Beaufort Sea): satellite observations and sediment trap measurements. Deep Sea Res I 57:125-142

Forest A, Osborne PD, Fortier L, Sampei M, Lowings MG (2015) Physical forcings and intense shelf-slope fluxes of particulate matter in the halocline waters of the Canadian Beaufort Sea during winter. Cont Shelf Res 101: $1-21$

* Garrison LP, Link JS (2000) Dietary guild structure of the fish community in the Northeast United States continental shelf ecosystem. Mar Ecol Prog Ser 202:231-240

* Gradinger RR, Kaufman MR, Bluhm BA (2009) Pivotal role of sea ice sediments in the seasonal development of nearshore Arctic fast ice biota. Mar Ecol Prog Ser 394:49-63

Grebmeier JM, Barry JP (1991) The influence of oceanographic processes on pelagic-benthic coupling in polar regions: a benthic perspective. J Mar Syst 2:495-518

* Grebmeier JM, Bluhm BA, Cooper LW, Denisenko SG, Iken K, Kędra M, Serratos C (2015) Time-series benthic community composition and biomass and associated environmental characteristics in the Chukchi Sea during the RUSALCA 2004-2012 program. Oceanography (Wash DC) 28:116-133

Hobson KA, Ambrose WG Jr, Renaud PE (1995) Sources of primary production, benthic-pelagic coupling, and trophic relationships within the Northeast Water Polynya: insights from $\delta^{13} \mathrm{C}$ and $\delta^{15} \mathrm{~N}$ analysis. Mar Ecol Prog Ser 128:1-10

Iken K, Bluhm B, Dunton K (2010) Benthic food-web structure under differing water mass properties in the southern Chukchi Sea. Deep Sea Res II 57:71-85

Jacob U, Mintenbeck K, Brey T, Knust R, Beyer K (2005) Stable isotope food web studies: a case for standardized sample treatment. Mar Ecol Prog Ser 287:251-253

Jones EP, Anderson LG, Swift JH (1998) Distribution of Atlantic and Pacific waters in the upper Arctic Ocean: implications for circulation. Geophys Res Lett 25: 765-768

Jumars PA, Dorgan KM, Lindsay SM (2015) Diet of worms emended: an update of polychaete feeding guilds. Annu Rev Mar Sci 7:497-520

Juul-Pedersen T, Michel C, Gosselin M (2008) Influence of the Mackenzie River plume on the sinking export of particulate material on the shelf. J Mar Syst 74:810-824

Källgren EK, Pedersen T, Nilssen EM (2015) Food resource partitioning between three sympatric fish species in Porsangerfjord, Norway. Polar Biol 38:583-589

Kędra M, Kuliński K, Walkusz W, Legeżyńska J (2012) The shallow benthic food web structure in the high Arctic does not follow seasonal changes in the surrounding environment. Estuar Coast Shelf Sci 114:183-191
Kopp D, Lefebvre S, Cachera M, Villanueva MC, Ernande B (2015) Reorganization of a marine trophic network along an inshore-offshore gradient due to stronger pelagicbenthic coupling in coastal areas. Prog Oceanogr 130: $157-171$

Lansard B, Mucci A, Miller LA, Macdonald RW, Gratton Y (2012) Seasonal variability of water mass distribution in the southeastern Beaufort Sea determined by total alkalinity and $\delta^{18} \mathrm{O}$. J Geophys Res 117:C03003

Layman CA, Arrington DA, Montaña CG, Post DM (2007) Can stable isotope ratios provide for community-wide measures of trophic structure? Ecology 88:42-48

*Logan JM, Jardine TD, Miller TJ, Bunn SE, Cunjak RA, Lutcavage ME (2008) Lipid corrections in carbon and nitrogen stable isotope analyses: comparison of chemical extraction and modelling methods. J Anim Ecol 77: 838-846

* Lovvorn JR, Cooper LW, Brooks ML, De Ruyck CC, Bump JK, Grebmeier JM (2005) Organic matter pathways to zooplankton and benthos under pack ice in late winter and open water in late summer in the north-central Bering Sea. Mar Ecol Prog Ser 291:135-150

*Macdonald RW, Solomon SM, Cranston RE, Welch HE, Yunker MB, Gobeil C (1998) A sediment and organic carbon budget for the Canadian Beaufort Shelf. Mar Geol 144:255-273

Macdonald TA, Burd BJ, Macdonald VI, van Roodselaar A (2010) Taxonomic and feeding guild classification for the marine benthic macroinvertebrates of the Strait of Georgia, British Columbia. Can Tech Rep Fish Aquat Sci 2874: $1-63$

*Magen C, Chaillou G, Crowe SA, Mucci A and others (2010) Origin and fate of particulate organic matter in the southern Beaufort Sea-Amundsen Gulf region, Canadian Arctic. Estuar Coast Shelf Sci 86:31-41

*Majewski AR, Atchison S, MacPhee S, Eert J, Niemi A, Michel C, Reist JD (2017) Marine fish community structure and habitat associations on the Canadian Beaufort shelf and slope. Deep Sea Res I 121:169-182

*Mariotti A (1983) Atmospheric nitrogen is a reliable standard for natural ${ }^{15} \mathrm{~N}$ abundance measurements. Nature 303:685-687

Matley JK, Fisk AT, Dick TA (2013) The foraging ecology of Arctic cod (Boreogadus saida) during open water (JulyAugust) in Allen Bay, Arctic Canada. Mar Biol 160: 2993-3004

* Matrai PA, Olson E, Suttles S, Hill V, Codispoti LA, Light B, Steele M (2013) Synthesis of primary production in the Arctic Ocean: I. Surface waters, 1954-2007. Prog Oceanogr 110:93-106

KMcLaughlin FA, Carmack EC, Macdonald RW, Bishop JKB (1996) Physical and geochemical properties across the Atlantic/Pacific water mass front in the southern Canadian Basin. J Geophys Res 101:1183-1197

*McLaughlin F, Shimada K, Carmack E, Itoh M, Nishino S (2005) The hydrography of the southern Canada Basin, 2002. Polar Biol 28:182-189

*McMahon KW, Ambrose WG Jr, Johnson BJ, Sun MY, Lopez GR, Clough LM, Carroll ML (2006) Benthic community response to ice algae and phytoplankton in $\mathrm{Ny}$ Ålesund, Svalbard. Mar Ecol Prog Ser 310:1-14

McTigue ND, Dunton KH (2014) Trophodynamics and organic matter assimilation pathways in the northeast Chukchi Sea, Alaska. Deep Sea Res II 102:84-96

Michel C, Legendre L, Taguchi S (1997) Coexistence of 
microalgal sedimentation and water column recycling in a seasonally ice-covered ecosystem (Saroma-ko Lagoon, Sea of Okhotsk, Japan). J Mar Syst 11:133-148

Mohan SD, Connelly TL, Harris CM, Dunton KH, MCClelland JW (2016) Seasonal trophic linkages in Arctic marine invertebrates assessed via fatty acids and compound-specific stable isotopes. Ecosphere 7:e01429

Morata N, Renaud PE, Brugel S, Hobson KA, Johnson BJ (2008) Spatial and seasonal variations in the pelagicbenthic coupling of the southeastern Beaufort Sea revealed by sedimentary biomarkers. Mar Ecol Prog Ser 371:47-63

Morata N, Poulin M, Renaud P (2011) A multiple biomarker approach to tracking the fate of an ice algal bloom to the sea floor. Polar Biol 34:101-112

Niemi A, Michel C, Dempsey M, Eert J, Reist J, Williams WJ (2015) Physical, chemical and biological oceanographic data from the Beaufort Regional Environmental Assessment: Marine Fishes Project, August-September 2013. Can Data Rep Hydrogr Ocean Science 198. Fisheries and Oceans Canada, Ottawa

Nikolopoulos A, Pickart RS, Fratantoni PS, Shimada K, Torres DJ, Jones EP (2009) The western Arctic boundary current at $152^{\circ} \mathrm{W}$ : structure, variability, and transport. Deep Sea Res II 56:1164-1181

North CA, Lovvorn JR, Kolts JM, Brooks ML, Cooper LW, Grebmeier JM (2014) Deposit-feeder diets in the Bering Sea: potential effects of climatic loss of sea ice-related microalgal blooms. Ecol Appl 24:1525-1542

Oxtoby LE, Mathis JT, Juranek LW, Wooller MJ (2016) Estimating stable carbon isotope values of microphytobenthos in the Arctic for application to food web studies. Polar Biol 39:473-483

Parsons TR, Maita Y, Lalli CM (1984) A manual of chemical and biological methods for seawater analysis. Pergamon Press, Oxford

* Peterson BJ, Fry B (1987) Stable isotopes in ecosystem studies. Annu Rev Ecol Syst 18:293-320

R Core Team (2016) R: a language and environment for statistical computing. R Foundation for Statistical Computing, Vienna

Renaud PE, Morata N, Ambrose WG Jr, Bowie JJ, Chiuchiolo A (2007a) Carbon cycling by seafloor communities on the eastern Beaufort Sea shelf. J Exp Mar Biol Ecol 349: 248-260

Renaud PE, Riedel A, Michel C, Morata N, Gosselin M, JuulPedersen T, Chiuchiolo A (2007b) Seasonal variation in benthic community oxygen demand: A response to an ice algal bloom in the Beaufort Sea, Canadian Arctic? J Mar Syst 67:1-12

Renaud PE, Morata N, Carroll ML, Denisenko SG, Reigstad M (2008) Pelagic-benthic coupling in the western Barents Sea: processes and time scales. Deep Sea Res II 55: 2372-2380

Renaud PE, Løkken TS, Jørgensen LL, Berge J, Johnson BJ (2015) Macroalgal detritus and food-web subsidies along an Arctic fjord depth-gradient. Front Mar Sci 2:31

Riaux-Gobin C, Klein B (1993) Microphytobenthic biomass measurement using HPLC and conventional pigment analysis. In: Kemp P, Sherr B, Sherr E, Cole J (eds) Hand-

Editorial responsibility: Antonio Bode,

A Coruña, Spain book of methods in aquatic microbial ecology. Lewis Publishers, New York, NY, p 369-376

Romanuk TN, Hayward A, Hutchings JA (2011) Trophic level scales positively with body size in fishes. Glob Ecol Biogeogr 20:231-240

Rousseuw PJ, Leroy AM (1987) Outlier diagnostics. In: Robust regression and outlier detection. John Wiley \& Sons, Hoboken, NJ, p 216-247

Koy V, Iken K, Archambault P (2014) Environmental drivers of the Canadian Arctic megabenthic communities. PLOS ONE 9:e100900

* Roy V, Iken K, Gosselin M, Tremblay JÉ, Bélanger S, Archambault P (2015) Benthic faunal assimilation pathways and depth-related changes in food-web structure across the Canadian Arctic. Deep Sea Res I 102:55-71

Sallon A, Michel C, Gosselin M (2011) Summertime primary production and carbon export in the southeastern Beaufort Sea during the low ice year of 2008. Polar Biol 34: 1989-2005

* Smith C, DeMaster D, Thomas C, Sršen P, Grange L, Evrard V, DeLeo F (2012) Pelagic-benthic coupling, food banks, and climate change on the west Antarctic Peninsula shelf. Oceanography (Wash DC) 25:188-201

* Smoot CA, Hopcroft RR (2017) Depth-stratified community structure of Beaufort Sea slope zooplankton and its relations to water masses. J Plankton Res 39:79-91

* Søreide JE, Carroll ML, Hop H, Ambrose WG Jr, Hegseth EN, Falk-Petersen S (2013) Sympagic-pelagic-benthic coupling in Arctic and Atlantic waters around Svalbard revealed by stable isotopic and fatty acid tracers. Mar Biol Res 9:831-850

* Stasko AD, Swanson H, Majewski A, Atchison S, Reist J, Power M (2016) Influences of depth and pelagic subsidies on the size-based trophic structure of Beaufort Sea fish communities. Mar Ecol Prog Ser 549:153-166

Stasko A, Swanson H, Atchison S, MacPhee S, Majewski A, Reist J, Power M (2017) Stable isotope data $\left(\delta^{15} \mathrm{~N}, \delta^{13} \mathrm{C}\right)$ for marine fish and invertebrates from the Beaufort Sea Marine Fishes Project, August-September 2012 and 2013. Can Data Rep Fish Aquat Sci 1270:1-63

Sun MY, Carroll ML, Ambrose MG, Clough LM, Li Z, Lopez GR (2007) Rapid consumption of phytoplankton and ice algae by Arctic soft-sediment benthic communities: evidence using natural and ${ }^{13} \mathrm{C}$-labeled food materials. J Mar Res 65:561-588

* Swanson HK, Lysy M, Power M, Stasko AD, Johnson JD, Reist JD (2015) A new probabilistic method for quantifying $n$-dimensional ecological niches and niche overlap. Ecology 96:318-324

* Tamelander T, Renaud PE, Hop H, Carroll ML, Ambrose WG Jr, Hobson KA (2006) Trophic relationships and pelagic-benthic coupling during summer in the Barents Sea Marginal Ice Zone, revealed by stable carbon and nitrogen isotope measurements. Mar Ecol Prog Ser 310: $33-46$

*Wassmann P, Reigstad M (2011) Future Arctic Ocean seasonal ice zones and implications for pelagic-benthic coupling. Oceanography (Wash DC) 24:220-231

WoRMS Editorial Board (2016) World Register of Marine Species. www.marinespecies.org (accessed 28 Oct 2016)

Submitted: July 18, 2017; Accepted: March 28, 2018

Proofs received from author(s): April 18, 2018 